Golden Gate University School of Law GGU Law Digital Commons

2013

\title{
Save Our Children: Overcoming the Narrative that Gays and Lesbians are Harmful to Children
}

\author{
Anthony S. Niedwiecki \\ Golden Gate University School of Law, aniedwiecki@ggu.edu
}

Follow this and additional works at: http:// digitalcommons.law.ggu.edu/pubs

Part of the Civil Rights and Discrimination Commons, Family Law Commons, and the Law and Gender Commons

\section{Recommended Citation}

21 Duke J. Gender L. \& Pol'y 21 (2013).

This Article is brought to you for free and open access by the Faculty Scholarship at GGU Law Digital Commons. It has been accepted for inclusion in Publications by an authorized administrator of GGU Law Digital Commons. For more information, please contact jfischer@ggu.edu. 


\title{
Save Our Children: Overcoming the Narrative that Gays and Lesbians are Harmful to Children
}

\begin{abstract}
ANTHONY NIEDWIECKI*
The United States has seen a dramatic shift in support for marriage equality for same-sex couples over the past decade, culminating in a recent gay rights victory in the U.S. Supreme Court. ${ }^{1}$ Also in the past year, several states have approved marriage rights for same-sex couples through the legislative or initiative process, reflecting the increasing cultural and political acceptance of marriage between same-sex partners. Polls support this cultural shift in the United States, with a 16\% jump in approval for same-sex marriage since 2001 and a $24 \%$ jump since $1996 .{ }^{2}$ This reflects a significant change in public opinion over a very short period of time and is in stark contrast to the large number of states that have passed and continue to enforce constitutional amendments banning marriage rights for same-sex couples. ${ }^{3}$

After the Hawaii Supreme Court held in 1993 that a ban on same-sex marriage was presumptively unconstitutional because it made an impermissible classification based on sex, ${ }^{4}$ opponents of same-sex marriage successfully used the initiative process to pass several state constitutional amendments to prevent similar rulings by other state courts. ${ }^{5}$ This backlash prompted many legal scholars to debate whether gay rights activists should have used the judicial system or the political process to gain marriage rights. ${ }^{6}$ On one side, scholars
\end{abstract}

Copyright (C) 2014 by Anthony Niedwiecki

* Anthony Niedwiecki is the Associate Dean for Skills, Experiential Learning, \& Assessment and Associate Professor of Law at The John Marshall Law School in Chicago. Professor Niedwiecki would like to thank his research assistants Ryan Westerman, Jamie Budler, and Michelle Hodgman, and The John Marshall Law School for its support and grant to write the article.

1. United States v. Windsor, 133 S. Ct. 2675 (2013).

2. May 2013 Political Survey, Question 36, PEW Res. CTR. FOR THE PEOPLE \& THE PResS, http://www,people-press,org/files/legacy-questionnaires/06-06-

13\%20LGBT\% 20public\% 20topline.pdf (last visited September 9, 2013).

3. Although the Supreme Court solely ruled the federal Defense of Marriage Act to be unconstitutional in Windsor, $133 \mathrm{~S}$. Ct. at 2682, Justice Kennedy's majority decision provides a good basis for finding the individual state bans on same-sex marriage to also be unconstitutional. In fact, marriage equality advocates almost immediately filed lawsuits challenging state bans. See, e.g., Tracy Jan, A Gay Rights Appeal to the Heart of Dixie: Same-Sex Couples Press Marriage Cause, Starting Down the Long Road to Change, THE BOS. GLOBE, July 14, 2013, at A1.

4. See Baehr v. Lewin, 852 P.2d 44, (Haw. 1993) ("It therefore follows, and we so hold, that (1) [the marriage statute] is presumed to be unconstitutional (2) unless Lewin, as an agent of the State of Hawaii, can show that (a) the statute's sex-based classification is justified by compelling state interests and (b) the statute is narrowly drawn to avoid unnecessary abridgements of the applicant couples' constitutional rights.").

5. See infra Part I.A.

6. See, e.g., infra notes 7-15. 
argued that pushing social change through the court system does not produce tangible results ${ }^{7}$ and may cause a backlash. ${ }^{8}$ Others argued that using the court system to push for social change can serve to educate the public, ${ }^{9}$ sway public opinion, ${ }^{10}$ and foster the political process. ${ }^{11}$ Some opponents of using the judicial system point to the continuing conflict associated with Roe $v$. Wade, ${ }^{12}$ and others point to the political backlash that resulted from a few state court decisions holding that bans on same-sex marriage were unconstitutional. ${ }^{13}$

In one of the leading books on whether courts can influence social change, THE HOLLOW HOPE, Gerald Rosenberg analyzes the extent that courts have helped advance many political and social causes in the last several decades, focusing on civil rights, abortion and women's rights, the environment, and criminal law. ${ }^{14}$ In his most recent edition, he details the fight for marriage equality for same-sex couples, discussing the backlash and the subsequent

7. E.g., Tomiko Brown-Nagin, Elites, Social Movements, and the Law: The Case of Affirmative Action, 105 COLUM. L. REV. 1436 (2005) (achieving only limited success in social movements shows the questionable ability of litigation to bring about social change).

8. E.g., Michael J. Klarman, Brown and Lawrence (and Goodridge), $104 \mathrm{MICH}, \mathrm{L}$. REV, 431, 473 (2005) ("Court rulings such as Brown and Goodridge produce political backlashes for three principal reasons: They raise the salience of an issue, they incite anger over 'outside interference' or 'judicial activism,' and they alter the order in which social change would otherwise have occurred.").

9. See, e.g., Beth Van Schaack, With All Deliberate Speed: Civil Human Rights Litigation as a Tool for Social Change, 57 VAND, L. REV, 2305, 2338 (2004) ("Litigation as a visible, public, and 'newsworthy' phenomenon can serve an educative function, by teaching the general public about international norms of behavior, calling attention to injustices, persuading changes of opinion, provoking a public outcry, and mobilizing grassroots campaigns.").

10. See, e.g., Mary Ziegler, Framing Change: Cause Lawyering, Constitutional Decisions, and Social Change, 94 MARQ, L, REV. 263, 267 (2010):

[M]ovements may sometimes benefit from using litigation rather than ordinary protest tactics to advance a particular frame. Because litigation can foster the expression of alternative arguments, the courts offer movements an opportunity to present a variety of possibly effective frames. When it does not yet have political influence, a movement may often have to rely on the media to publicize a frame. In such a case, movements have reason to silence dissent, for the media are likely to focus on internal divisions once they are discovered rather than on the movement's message. Consequently, social movement organizations may press members to speak with a single voice and to suppress alternative frames. By contrast, in applying rules governing pleading and the submission of amicus briefs, the courts may foster forms of dissent that would prove too costly for movements in the political arena.

11. See, e.g., Robert S. Chang, The Fred T. Korematsu Center for Law and Equality and Its Vision for Social Change, 7 STAN. J. C.R. \& C.L. 197, 203 (2011) ("Instead of operating under what Rosenberg understands to be a naïve and misguided reliance on the courts, LGBT movement lawyers had a sophisticated political understanding and understood that effective advocacy required multiple strategies... [including] advocacy across different domains (courts, legislatures, media), spanning different levels (federal, state, local), and deploying different tactics (litigation, legislative advocacy, public education).").

12. Robert Post \& Reva Siegel, Roe Rage: Democratic Constitutionalism and Backlash, 42 HARV. C.R.C.L. L. REV, 373, 374 (2007).

13. See, e.g., Klarman, supra note 8 , at 466-70 (stating that political backlash of Lawrence and Goodridge resulted in state constitutional amendments banning same-sex marriage, mobilizing conservative Christian citizens to vote in unprecedented numbers, helping Republican senators gain seats in close election races, aiding Republicans in taking the majority in the Senate, and sensationalizing the issue of same-sex marriage to the point that conservative political platforms will continue to focus on it).

14. See generally GERALD N. ROSENBERG, THE HOLLOW HOPE (2d ed. 2008). 
change in public opinion, but he asserts that the benefit of using the court system to advance civil rights is generally outweighed by the subsequent political cost. ${ }^{15}$

This discussion about the role that courts should play in advancing civil rights fails to address the difference in how voters and judges evaluate arguments. A communication theory by Professor Walter Fisher proves instructive in understanding this difference. Fisher's theory, called the "narrative paradigm," presumes that all humans are storytellers and communicate mostly through stories. ${ }^{16}$ People evaluate the stories they hear based on their own experiences, views of morality, and values. ${ }^{17}$ Fisher labels this evaluative process "narrative rationality." $18 \mathrm{He}$ believes that only experts have the skills and abilities to use logic and reason, where most lay people make judgments based on culture, biography, and their life experiences. ${ }^{19}$ Under Fisher's theory, voters are lay people who are more likely to evaluate political arguments using their own life experiences and views on morality, while judges are experts who are more likely to use reason and logic to evaluate legal arguments.

This difference between the rhetoric used in initiative campaigns and the rhetoric used in courts helps explain why gay rights activists have generally been much more successful at advancing marriage rights through the judicial system than through the political process. ${ }^{20}$ When a few local governments were passing laws that protected gay people from discrimination, gay rights opponents learned very quickly that they could reverse or block those laws through the ballot initiative process. ${ }^{21}$ Gay rights opponents were effective, winning almost every ballot initiative from 1970 until recently.22 They were successful because their political campaigns focused on how gays and lesbians were harmful to children, from equating homosexuality with pedophilia to claiming that schools would be required to teach about and promote homosexuality in elementary schools. ${ }^{23}$ Initially, gay rights activists failed to address the claims that gays and lesbians are harmful to children, instead focusing their arguments on the broader themes of equality and human rights. ${ }^{24}$

As a result of these unchallenged depictions of gay people in the first initiative campaigns in the 1970s and 1980s, a narrative began to develop that gays and lesbians were harmful to children. ${ }^{25}$ This narrative was quickly strengthened by several events where gay people were often depicted in a

\footnotetext{
15. See ROSENBERG, supra note 14, pt. 4 (detailing a study on the changes in opinions about samesex marriage to show "that litigation as a means of obtaining the right to same-sex marriage has not been successful ${ }^{\prime \prime}$ ).

16. Walter R. Fisher, Human COMMUnication as NarRation: TOWARD a PHilosophy of REASON, VALUE, AND ACTION 64 (1987).

17. Id.

18. Id.

19. Id. A description of his theory can be found in Part II, infra, and the accompanying notes.

20. For a detailed examination of the political and judicial fights over gay rights, see Part I, infra and accompanying notes.

21. See Part I, infra.

22. See Part I, infra.

23. See Part III, infra.

24. See infra notes 162-166 and accompanying text.

25. See Part III, infra.
} 
negative light, including the emergence of HIV/AIDS, the political rise of the Religious Right, and the Catholic Church scandal where male priests were abusing boys. ${ }^{26}$

With opponents of gay rights successfully using this well-developed narrative in the political process to limit same-sex marriage, gay rights proponents often used the judicial system to rebut the narrative, given that judges are generally persuaded by legal reasoning and logic. ${ }^{27}$ Eventually, through trials and hearings, gay rights proponents were able to effectively debunk the idea that gay people were harmful to children, thereby undermining many of the reasons states put forward in support of marriage bans. ${ }^{28}$ With courts awarding marriage rights to same-sex couples, same-sex spouses became much more visible to the general public. As a result, positive depictions of samesex married couples with children emerged and became part of our culture and media. ${ }^{29}$ As Fisher's theory illustrates, these positive depictions began to break down the decades-old narrative that gay people are harmful to children. These positive narratives resulted in major victories for marriage equality supporters both in the Supreme Court and through the political process.

This paper focuses on how gay rights activists had no real choice but to use the court system to advance marriage rights for same-sex couples because they were unable to use the political process to effectively rebut the claim that gays and lesbian were harmful to children. Part I begins with an overview of the ways in which the initiative process has been used to limit gay rights and prevent marriage equality. It then details how, in contrast to the political process, courts have been more receptive to advancing marriage rights for same-sex couples. Part II details Walter Fisher's narrative paradigm as a theory of communication and rhetoric, which provides a theoretical basis for why courts are more likely to challenge arguments against same-sex marriage while voters are likely to adopt arguments if they ring true to their own experiences and values. Part III applies Fisher's theory to show how gay rights opponents, in their first initiative campaigns to rescind gay rights, effectively developed a narrative that gay people were harmful to children. This narrative was subsequently cemented into the nation's collective psyche through the HIV/AIDS crisis, the rise of the Moral Majority, the Catholic Church molestation scandal, and the Boy Scouts' ban on gay members. Part IV uses the California Proposition 8 campaign and subsequent federal trial to provide a detailed example of the difference in the

26. See Part III (B), infra.

27. Michael Smith, Advanced Legal Writing: Theories and Strategies in Persuasive WRITING 23 ( $2 \mathrm{~d}$ ed. 2008) ("legal writing audiences are persuaded most by logical reasoning based on legal authorities and precedent").

28. See, e.g., Perry v. Schwarzenegger, 704 F. Supp. 2d 921, 973, 980-81 (N.D. Cal. 2010); In re Adoption of John Doe \& James Doe, 2008 WL 5006172, at 37 (Fla. Miami-Dade Cir. Ct. 2008).

29. For example, the television show Modern Family features a gay couple who adopts a girl. Luaine Lee, 'Modern Family' Writers Follow Their Instincts: The Key Is Getting Network Executives To Trust Them, One Says, CHICAGo TRIBUNE, Aug. 6, 2012, at 5; Mark Vigorito, Why Neil Patrick Harris is Just the Worst, HUFFINGTON POST (Aug. 4, 2013, 10:02 AM) http://www.huffingtonpost.com/markvigorito/why-neil-patrick-harris-is-just-the-worst_b_3697243.html. 
way voters and courts evaluate the narrative that gay people are harmful to children, with the narrative swaying voters but being rejected by the court.

\section{THE USE OF THE INITIATIVE PROCESS TO RESTRICT GAY RigHTS}

Ballot measures, whether through an initiative process or limit or as a means of amending a state constitution, have been used frequently to repeal the expansion of gay rights. ${ }^{30}$ The first high-profile initiative, which sought to repeal a local ordinance that prohibited discrimination based on "sexual preference," took place in Dade County, Florida in $1977 . .^{31}$ Led by community and religious leaders, voters repealed the ordinance by a large margin. ${ }^{32}$ Quickly following the victory in Florida, the initiative process was used to repeal anti-discrimination ordinances in municipalities across the country, including in St. Paul, Minnesota, Eugene, Oregon, and Wichita, Kansas. 33

In the late 1980s and early 1990s, several other initiatives repealing antidiscrimination laws passed. ${ }^{34}$ In 1992, the citizens of Colorado took the initiative

30. See William E. Adams, Jr., Is it Animus or a Difference of Opinion? The Problems Caused by the Invidious Intent of Anti-Gay Ballot Measures, 34 WILLAMETTE L. REV. 449, 458-62 (1998) (detailing the numerous ballot measures used to revoke anti-discrimination laws, ban gay teachers, prohibit any future anti-discrimination laws, ban domestic partnership laws).

31. Bruce J. Winick, The Dade County Human Rights Ordinance of 1977: Testimony Revisited in Commemoration of Its Twenty-Fifth Anniversary, 11 LAW \& SEXUALITY 1, 2 (2002) (discussing the development of the original ordinance that prevented discrimination based on their "sexual or affectional preference"). See also DUDLEY CLENDINEN \& ADAM NAGOURNEY, OUT FOR GOOD: THE StRUgGle TO BuILD A GAY RightS MOVEMENT IN AMERICA 295, 299 (1999). Early in the gay rights movement, the term "sexual preference" was used instead of the now common "sexual orientation." See, e.g., Voyles v. Ralph K. Davies Med. Ctr., 403 F. Supp. 456, 457 (N.D. Cal. 1975), aff'd 570 F.2d 354 (9th Cir. 1978) ("[V]arious members of the House of Representatives have, on three separate occasions during this year alone, introduced as of yet unenacted legislation which would amend $\S$ 2000e-2(a) to include 'affectional or sexual preference' as additional basis upon which employers are precluded from discharging their employees."); Oiler v. Winn-Dixie La., Inc., No. CIV.A. 00-3114, 2002 WL 31098541, at *4 (E.D. La. 2002) ("From 1981 through 2001, thirty-one proposed bills have been introduced in the United States Senate and the House of Representatives which have attempted to amend Title VII and prohibit employment discrimination on the basis of affectional or sexual orientation....").

32. See CLENDINEN \& NAGOURNEY, supra note 31, at 308 ("The final vote was 202,319 in favor of repeal to 89,562 against; almost 70 percent of the voters had voted against gay rights."); 25 Years Later, Miami Again Has Gay Rights Fight on Its Hands, L.A. TIMES (Sept. 5, 2002), available at http://articles.latimes.com/2002/sep/05/nation/na-gayrights5 (repealing of a Miami-Dade County ordinance protecting gays from discrimination because of Anita Bryant's campaign).

33. See Adams, supra note 30, at 458; CLENDINEN \& NAGOURNEY, supra note 31, at 327 ("In St. Paul on April 25, in Wichita on May 9, and in Eugene on May 23, 1978, concerned and angry voters ... repealed each city's gay rights ordinance.... The margin of defeat was 2 to 1 in St. Paul, 4 to 1 in Wichita and 2 to 1 in Eugene.,").

34. See Adams, supra note 30, at 460. See also Allan H. Terl, An Essay on the History of Lesbian and Gay Rights in Florida, 24 NOVA L. REV. 793, 833 (2000) (legalizing discrimination against homosexuals in Tampa, Florida); James Drew, Activists Seek Repeal of Roadblock to Gay Rights, THE BLADE (July 11, 2004), http:/ / www.toledoblade.com/State/2004/07/11/ Activists-seek-repeal-of-roadblock-to-gayrights.html (preventing the city of Cincinnati from giving protected class status to gays, lesbians, and bisexuals); Donna O'Neal, Anti-Gay Measure Could Repeal Rights of Others, Foes Say, SUN SENTINEL, Dec. 7, 1993, available at http://articles.sun-sentinel.com/1993-12-07/news/9312070552_1_anti-gayrights-measure-repeal-homosexuals (restricting rights of gays in Lewiston, Maine); Kery Murakami, Initiatize 677 - Gay-Rights Issue Loses; Foes See An Opening, THE SEATTLE TIMES, Nov. 5, 1997, available at 
process a step further and passed a constitutional amendment known as Amendment Two, which prohibited adding sexual orientation to any ordinance, statute, or regulation and repealed those that already passed. ${ }^{35}$ This amendment ultimately became the subject of Romer $v$. Evans, the Supreme Court case that applied the Equal Protection Clause to gay and lesbian people. ${ }^{36}$ The initiative process continued to be used throughout the 1990 s and has consistently been used to stop the push for marriage rights for same-sex couples until the recent rejection of a proposed anti-gay marriage amendment in Minnesota. ${ }^{37}$

\section{A. Early Court Decisions on Marriage Rights for Same-Sex Couples and the Political Backlash that Ensued}

The initiative process became the predominant tool for those seeking to prohibit same-sex marriage after the Hawaii Supreme Court ruled in 1993 that denying marriage to same-sex couples violated Hawaii's Equal Protection Clause. ${ }^{38}$ The court reasoned that denying marriage rights to same-sex couples

http://community.seattletimes.nwsource.com/archive/?date=19971105\&slug=2570520 (reporting unsuccessful attempt to enact gay rights measure); Eric Lichtblau \& Steven R. Churm, Tax for Roads Loses; Anti-Gay Forces Win : Bias: Passage of Measure $N$ will repeal portion of Irvine law banning discrimination based on sexual orientation, L.A. TIMES, Nov. 8, 1989, available at http://articles.latimes.com/1989-11-08/news/mn-1049_1_sexual-orientation ("By approving Measure $N$, voters removed protections for homosexuals from the city's 15-month-old human rights ordinance.").

35. COLO. CONST. art. II, $\$ 30$ b (West, Westlaw through Nov. 12 General Election) ("Neither the State of Colorado, through any of its branches or departments, nor any of its agencies, political subdivisions, municipalities or school districts, shall enact, adopt or enforce any statute, regulation, ordinance or policy whereby homosexual, lesbian or bisexual orientation, conduct, practices or relationships shall constitute or otherwise be the basis of or entitle any person or class of persons to have or claim any minority status, quota preferences, protected status or claim of discrimination. This Section of the Constitution shall be in all respects self-executing."). See DENVER ReV. MUNICIPAL CODE, art. IV, \&\$ 28-91 to -116 (1991); Romer v. Evans, 517 U.S. 620, 623-24 (1996) ("Among the government enactments that would be repealed by Amendment 2 are the following; the Denver, Boulder, Aspen, Telluride and Crested Butte ordinances prohibiting discrimination in employment, housing and public accommodations on the basis of sexual orientation.) Brief for Respondent, Romer 517 U.S. 620 (No. 94-1039), 1995 WL 370335 at *5 (describing the Aspen Municipal code as an ordinance prohibiting discrimination against both heterosexuals and homosexuals in "employment, housing, and public accommodations within the city, including discrimination on the basis of sexual orientation"); Linda Greenhouse, Supreme Court to Rule on Anti-Gay Rights Law in Colorado, N.Y. TIMES (Feb. 22, 1995), http://www.nytimes.com/1995/02/22/us/supreme-court-to-rule-on-anti-gayrights-law-in-colorado.html (passing of ordinances in Colorado cities of Boulder, Denver, and Aspen that prohibit discrimination against homosexuals).

36. Romer, 517 U.S. at 623 ("The Equal Protection Clause... requires us to hold invalid a provision of Colorado's Constitution. The enactment challenged in this case is an amendment to the Constitution of the State of Colorado, adopted in a 1992 statewide referendum.").

37. Gay Marriage Approzed by Washington Voters, WASH. POST, Nov, 9, 2012, at A12.

38. Baehr v. Lewin, 852 P.2d 44, 67 (Haw. 1993) (presuming sex-based classification to be unconstitutional unless justified by a compelling state interest that is narrowly drawn to avoid unnecessary infringements on petitioners' constitutional rights). The state eventually had a trial on the state's justifications for the ban, and the trial court ruled that the state did not have a legitimate reason for prohibiting same-sex couples from marrying. Baehr v. Miike, CIV. No. 91-1394, 1996 WL 694235 (Haw. Cir. Ct. Dec. 3, 1996), aff'd, 950 P.2d 1234, 1235 (Haw, 1997) ("The sex-based classification in HRS \$ 572-1, on its face and as applied, is unconstitutional and in violation of the equal protection clause of article I, section 5 of the Hawaii Constitution."). 
was a form of sex discrimination. ${ }^{39}$ Within a couple of years, the initiative process was used in Hawaii to overturn the decision of the Hawaii Supreme Court and to place in its constitution the right of the legislature to define marriage, which it defined as a union between one man and one woman. ${ }^{40}$

In 1999, the Vermont Supreme Court ruled that same-sex couples must receive the same rights as opposite-sex couples. ${ }^{41}$ Then, after a couple of courts held the denial of marriage rights to same-sex couples to be unconstitutional under state law, gay rights opponents began a sustained effort to amend state constitutions to prohibit marriage for same-sex couples. ${ }^{42}$ In 2000, Nebraska went even further and passed a broad amendment that prohibited granting any legal status or marriage rights to same-sex couples.43 Subsequently, similar amendments passed in several other states, and a large majority of states now have a constitutional ban on same-sex marriages. ${ }^{44}$ Some states passed initiatives

39. Lewin, 852 P. $2 \mathrm{~d}$ at 68 ("[T]he burden will rest on Lewin to overcome the presumption that HRS $\$ 572-1$ is unconstitutional by demonstrating that it furthers compelling state interests and is narrowly drawn to avoid unnecessary abridgements of constitutional rights.").

40. HAW. CONST. art. I, \& 23 ("The legislature shall have the power to reserve marriage to opposite-sex couples."). Unlike many of the initiatives that followed in other states, this amendment took the power to provide equal marriage rights away from the courts and gave it to the legislature. Subsequently, the Hawaii Supreme Court dismissed the earlier case because of the amendment.

41. Baker v. Vermont, 744 A.2d 864, 887 (Vt. 1999) ("We hold that the State is constitutionally required to extend to same-sex couples the common benefits and protections that flow from marriage under Vermont law.").

42. See Scott L. Cummings \& Douglas NeJaime, Lawyerin-2g for Marriage Equality, 57 UCLA L. REv, 1235, 1260 (2010) ("[California's] Proposition 22 sought to . . . amend the Family Code to prohibit California from recognizing any marriage other than between a man and a woman."); William $\mathrm{H}$. Stoddard, Esq. \& G. Mark Albright, Esq., Question 2: A Necessary Defense of Marriage, NEv. LAW. 17, Nov, 2002, at 28 ("In approving Question 2, the voters of Nevada would not only join Alaska and Nebraska in amending their state constitutions, but also the people of Hawaii, who amended their constitution in 1998 to allow the legislature to define marriage as the union of a man and a woman[.]"); Christopher Rizzo, Banning State Recognition of Same-Sex Relationships: Constitutional Implications of Nebraska's Initiative 416, 11 J.L. \& POL'Y 1, 2002, at 1-2 (passing of Nebraska Constitutional amendment prohibiting same-sex marriage by 70 percent of voters); 1998 Ballot Initiatives, N.Y. TIMES, http://theater.nytimes.com/library/politics/camp/ballots/98ballots.1.html (last visited Oct. 2, 2013) (listing Alaska's gay marriage ban as "Ballot Measure 2"). See also Mathew 5. Nosanchuk, Response: No Substitutions, Please, 100 GEO. L.J. 1989, 1999 (2012) ("From 2004 to 2009, there were thirty-eight referenda and initiatives on ballots around the country, and marriage opponents won thirty of them.").

43. NEB. CONST. art. I, \& 29 ("Only marriage between a man and a woman shall be valid or recognized in Nebraska. The uniting of two persons of the same sex in a civil union, domestic partnership, or other similar same-sex relationship shall not be valid or recognized in Nebraska."). See Rizzo, supra note 42, at 2 (referring to Nebraska's referendum for Constitutional amendment prohibiting same-sex marriage as "Initiative $416^{\prime \prime}$ ).

44. Ala. CONST. art. I, § 36.03; ALASKa CONST. art. I, \$ 25; ARIZ. CONST. art. XXX, § 1; ARK. CONST. amend. LXXXIII, \& 1; CAL. CONST. art. I, \$ 7.5; COLO. CONST. art. II, $\$ 31$; FLA. CONST. art. I, $\$$ 27; GA. CONST. art. I, \& 4; HAW. CONST. art. I, \& 23; IDAHO CONST, art. III, § 28; KAN. CONST. art. XV, \& 16; KY. CONST. \& 233A; LA. CONST, art. XII, \& 15; MICH. CONST. art. I, \& 25; MISS. CONST. art. XIV, \& 263A; MO. ConST, art. I, \& 33; MONT. CONST, art. XIII, \& 7; NEB. CONST, art. I, \& 29; NEV. CONST. art. I, \& 21; N.C. CONST. art. XIV, \& 6; N.D. CONST. art. XI, \& 28; OHIO CONST. art. XV, \& 11; OKLA. CONST. art. II, \& 35; OR. CONST. art. XV, \& 5a; S.C. CONST. art. XVII, \& 15; S.D. CONST. art. XXI, \& 9; TENN. CONST. art. XI, \& 18; TEX. CONST. art. I, \& 32; UTAH CONST. art. I, \& 29; VA. CONST. art. I, § 15-A; WIS. CONST. art. XIII, $\$ 13$. 
that simply defined marriage as between one man and one woman, ${ }^{45}$ while others passed broader amendments that could potentially be used to prohibit civil unions and domestic partnerships. ${ }^{46}$

Shortly after the Hawaii Supreme Court first found that marriage rights should be afforded to same-sex couples, the federal government took action. In the fall of 1996, Congress passed DOMA and President Clinton signed it into law. ${ }^{47}$ This federal law defines marriage as between one man and one woman, prohibits the recognition of marriages for same-sex couples, and allows states to refuse to recognize same-sex marriages performed in other states. ${ }^{48}$

\section{MARRIAGE FIGHT CONTINUES IN THE COURTS}

Based on the success in the Hawaii and Vermont courts, gay rights supporters continued to take their fight for marriage rights to the courts. In 2003, marriage rights supporters had their first long-term victory when the Massachusetts Supreme Court ruled that the ban on marriage for same-sex couples violated the state constitution. ${ }^{49}$ In 2004, Massachusetts became the first state to allow same-sex couples to marry. ${ }^{50}$ In response, more states passed

45. See, e.g., ALASKA CONST, art. I, $\S 25$ ("To be valid or recognized in this State, a marriage may exist only between one man and one woman."); COLO. CONST. art. II, $\$ 31$ ("Only a union of one man and one woman shall be valid or recognized as a marriage in this state."); MISs. CONST. art. XIV, $\S$ 263A ("Marriage may take place and may be valid under the laws of this state only between a man and a woman."); OR. CONST. art. XV, § 5a ("It is the policy of Oregon, and its political subdivisions, that only a marriage between one man and one woman shall be valid or legally recognized as a marriage.").

46. See, e.g., FLA. CONST, art. I, \& 27 ("Inasmuch as marriage is the legal union of only one man and one woman as husband and wife, no other legal union that is treated as marriage or the substantial equivalent thereof shall be valid or recognized."); KAN. CONST. art. XV, § 16 ("Marriage shall be constituted by one man and one woman only... No relationship, other than a marriage, shall be recognized by the state as entitling the parties to the rights or incidents of marriage."); MICH. CONST. art. I, \& 25 ("To secure and preserve the benefits of marriage for our society and for future generations of children, the union of one man and one woman in marriage shall be the only agreement recognized as a marriage or similar union for any purpose."); OHIO CONST. art. XV, \& 11 ("Only a union between one man and one woman may be a marriage valid in or recognized by this state and its political subdivisions."); UTAH CONST. art. I, § 29 ("(1) Marriage consists only of the legal union between a man and a woman. (2) No other domestic union, however denominated, may be recognized as a marriage or given the same or substantially equivalent legal effect.").

47. 1 U.S.C.A. \& 7 (1996); 28 U.S.C.A. \& 1738C (1996).

48. 1 U.S.C.A. $\$ 7$ ("[T]he word 'marriage' means only a legal union between one man and one woman as husband and wife, and the word 'spouse' refers only to a person of the opposite sex who is a husband or a wife."); 28 U.S.C.A. \$1738C ("No State, territory, or possession of the United States, or Indian tribe, shall be required to give effect to any public act, record, or judicial proceeding of any other State, territory, possession, or tribe respecting a relationship between persons of the same sex that is treated as a marriage under the laws of such other State, territory, possession, or tribe, or a right or claim arising from such relationship.").

49. Goodridge v. Dept. of Pub. Health, 798 N.E.2d 941, 969 (Mass. 2003) ("We declare that barring an individual from the protections, benefits, and obligations of civil marriage solely because that person would marry a person of the same sex violates the Massachusetts Constitution."). See also In re Opinions of the Justices to the Senate, 802 N.E.2d 565 (Mass. 2004) (rendering an advisory opinion in the negative on the constitutionality of a civil union bill that excludes same-sex couples from the institution of marriage).

50. Matt Viser and Michael Levenson, Mass. Helped Propel Marriage Equality Change, BosToN GLOBE, June 17, 2013, available at http://www.bostonglobe.com/news/nation/2013/06/26/roots- 
constitutional amendments in November 2004 banning marriage rights for samesex couples. ${ }^{51}$ After so many political losses, it became clear to proponents of equal marriage rights for same-sex couples that their best chance was to continue fighting through the courts. ${ }^{52}$ Gay rights proponents filed and won lawsuits in California, New Jersey, Connecticut, and Iowa. ${ }^{53}$ After the California Supreme Court found a ban on same-sex marriages unconstitutional, California issued marriage licenses to same-sex couples for a few months until voters approved Proposition 8, which limited marriage to opposite-sex couples.54 Gay rights proponents subsequently filed a federal lawsuit challenging the constitutionality of Proposition 8.55 After a lengthy bench trial, the Northern District Court of California held the proposition to be unconstitutional and ordered California to

supreme-court-decision-overturning-doma-are

massachusetts/G31gFFEZbXLvgIOIWnFojO/ story.html. MASS. GEN. LAWS ANN. ch. 207, $\$ 1$ et seq. (West 2005).

51. See Professor Mark F. Scurti, Same Sex Marriage: Is Maryland Ready? 35 U. BALT. L. F. 128, 13334 (2005) ("[T]he results of the 2004 elections produced eleven states passing constitutional amendments banning same sex marriages."); see also Dara E. Purvis, Evaluating Legal Activism: A Response to Rosenberg, 17 BUFF. J. GENDER, L. \& SOC. POL'Y, 2009, at 4 ("Analysts also discussed the possibility that the issue of same-sex marriage was a significant factor, even a determinative one, in the [2004] presidential election. ...").

52. See Michael A. Lindenberger, Are the Courts Ahead of the Public on Gay Rights?, TIME, Nov. 23, 2010, http:/ / www.time.com/time/nation/article/0,8599,2032721,00,html ("many activists feel the judiciary is still their best avenue to win change"); see also Douglas NeJaime, The Legal Mobilization Dilemma, 61 EMORY L.J. 663, 688 (2012) (explaining the benefits of pursuing change through litigation: "[A]ny movement member can get into court and can do so without community support or substantial material resources. The individualist model of litigation, embodied in both procedural and ethical rules, contrasts sharply with more democratic, consensus-based models that characterize group decision making in other institutional arenas."). But see Purvis, supra note 51, at 14-15 (quoting author and law professor Gerald Rosenberg: "Forgetting the lessons of history, the Progressive agenda was hijacked by a group of elite, well-educated and comparatively wealthy lawyers who uncritically believed that rights trump politics and that successfully arguing before judges is equivalent to building and sustaining political movements.").

53. Lewis v. Harris, 908 A.2d 196, 224 (N.J. 2006) ("To comply with the equal protection guarantee of Article I, Paragraph 1 of the New Jersey Constitution, the State must provide to committed same-sex couples, on equal terms, the full rights and benefits enjoyed by heterosexual married couples."); In re Marriage Cases, 183 P.3d 384, 433-34 (Cal. 2008) ("[W]e conclude that the right to marry, as embodied in article $\mathrm{I}$, sections 1 and 7 of the California Constitution, guarantees same-sex couples the same substantive constitutional rights as opposite-sex couples to choose one's life partner and enter with that person into a committed, officially recognized, and protected family relationship that enjoys all of the constitutionally based incidents of marriage."); Kerrigan v. Comm'r of Pub. Health, 957 A.2d 407, 482 (Conn. 2008) ("In accordance with these state constitutional requirements, same sex couples cannot be denied the freedom to marry."); Varnum v. Brien, 763 N.W.2d 862, 906 (Iowa 2009) ("If gay and lesbian people must submit to different treatment without an exceedingly persuasive justification, they are deprived of the benefits of the principle of equal protection upon which the rule of law is founded. Iowa Code section 595.2 denies gay and lesbian people the equal protection of the law promised by the Iowa Constitution.").

54. See Perry v. Schwarzenegger, 704 F. Supp. 2d 921, 927 (N.D. Cal. 2010), affd sub nom., Perry v. Brown, 671 F.3d 1052 (9th Cir. 2012) (reciting Proposition 8: "Only marriage between a man and a woman is valid or recognized in California."); CAL. CONST. art. I, $\$ 7.5$ ("Only marriage between a man and a woman is valid or recognized in California."); see also Maura Dolan \& Jessica Garrison, Gay Married Couples Face Legal Limbo if Prop. 8 Passes, L.A. TIMEs, Oct. 30, 2008 http:/ / www.latimes.com/news/local/la-me-marriagelaw30-2008oct30,0,3560871.story (estimating approximately 16,000 same-sex couples married after same-sex marriage became legal and before Proposition 8 prohibited marriage between members of the same sex).

55. Schwarzenegger, 704 F. Supp. $2 \mathrm{~d}$ at 921. 
resume issuing marriage licenses to same-sex couples. ${ }^{56}$ The Ninth Circuit issued a stay on enforcing the order until the appeals process was completed. ${ }^{57}$ California officials refused to appeal the decision beyond the district court, so the proponents of Proposition 8 appealed to the Ninth Circuit Court of Appeals, which then affirmed the district court's decision on more limited grounds. ${ }^{58}$ The Supreme Court subsequently decided that the proponents of Proposition 8 did not have standing to defend the law in the Ninth Circuit or at the Supreme Court, so the district court's opinion remained in place. ${ }^{59}$ Almost immediately after the Supreme Court issued its opinion, the Ninth Circuit lifted its stay and the state began issuing marriage licenses to same-sex couples. ${ }^{60}$

In addition to challenging statewide bans on same-sex marriage, gay rights proponents began challenging the constitutionality of DOMA in federal court. Numerous courts, including the U.S. Supreme Court, found DOMA unconstitutional because the government had no legitimate reason for denying same-sex married couples the same benefits afforded opposite-sex married couples. ${ }^{61}$ Early in his administration, President Obama decided not to appeal the many lower court decisions finding DOMA unconstitutional because he also believed the law to be unconstitutional. ${ }^{62}$ Instead, the Republican leadership of

56. Id. at 921-1004 (holding Proposition 8 to be unconstitutional in an 83-page opinion).

57. Perry v. Schwarzenegger, No. 10-16696, 2010 WL 3212786, at *1 (9th Cir. Aug 16, 2010)

58. Perry v. Brown, 671 F.3d 1052 (9th Cir. 2012) (holding that: (1) the people of California, through proponents of the ballot measure, had to be allowed under Article III to defend validity of their use of initiative power in federal courts, including on appeal; (2) messages that proponents communicated to voters to encourage their approval of the proposition were "adjudicative facts" to which the court had to give deferential weight; (3) the amendment was not rationally related to California's interest in childrearing and responsible procreation; (4) the amendment was not rationally related to California's interest in "proceed[ing] with caution" when considering changes to the definition of marriage; (5) the amendment was not rationally related to California's interest in protecting religious liberty; (6) the amendment was not rationally related to California's interest in preventing children from being taught about same-sex marriage in schools; (7) tradition alone could not serve as justification for taking away the right from gays and lesbians to use the designation of "marriage" that already had been granted; and (8) the judge did not abuse his discretion in denying the motion to vacate judgment.).

59. Hollingsworth v. Perry, No. 12-144, slip op. (U.S. June 26, 2013) (holding that the petitioners did not have standing to defend the law).

60. Brown, 671 F.3d at 1059; Perry v. Brown, No. 10-16696, slip op. (9th Cir. June 28, 2013) (rescinding the stay on enforcement of the law and allowing the state to issue same-sex marriage licenses).

61. See, e.g., Windsor v. United States, 133 S.Ct. 786 (2013); Mass. v. U.S. Dep't of Health \& Human Servs., 682 F.3d 1 (1st Cir. 2012); Golinski v. Office of Pers. Mgmt. 824 F.Supp.2d 968 (N.D. Cal, 2012), appeal dismissed, Nos, 12-15388 and 12-15409 (9th Cir.); Pedersen v. Office of Pers. Mgmt., 881 F.Supp.2d 294 (D. Conn. 2012); Dragovich v. Dep't of the Treasury, 848 F.Supp.2d 1091 (N.D. Cal. 2012); McLaughlin v. Panetta, No. 1:11-cv-11905-RGS (D.C. Mass. July 19, 2013); Cooper-Harris v. Dep't of Veterans Affairs, CV12-0887-CBM (D.C. Cal, Feb. 1, 2012); Cardona v. Shinseki, No, 09-0741, 2010 WL 4703848 (Ct. Vet. App. Nov. 12, 2010); Blesch v. Holder No. CV12-1578, 2012 WL 1965401(E.D.N.Y. May 31, 2012); In re Balas, No. 2:11-bk-17831 TD (C.D. Cal Bank. June 13, 2011); Bishop v. United States, No. 04-CV-848, 2009 WL 4505951 (N.D. Okla. 2009); Lui v. Holder, No. 0972068 (9th Cir. Aug. 5, 2013).

62. See Abby Goodnough, Appeals Court Hears Arguments on Gay Marriage Law, N.Y. TIMES, Apr. 4, 2012, http://www nytimes.com/2012/04/05/us/court-hears-arguments-on-defense-of-marriageact.html?_r=0 (reporting Obama administration will no longer pursue appeals defending DOMA); $\mathrm{Z}$. Byron Wolf, President Obama Instructs Justice Department to Stop Defending Defense of Marriage Act calls 
the U.S. House of Representatives decided to appeal United States v. Windsor, a DOMA case, to the U.S. Supreme Court. ${ }^{63}$

The courts addressing the constitutionality of bans on marriage for same-sex couples have generally done a thorough job of evaluating the government's interests for these bans to determine if they are constitutional. In these cases, the main reasons often proffered by the government include:

Protecting the stability of opposite-sex couples because women can get pregnant accidently. Gay couples must engage in more planning to have children, so their relationships are already stable. ${ }^{64}$

Preference for children to be raised by a mom and dad 65

Promote procreation 66

Nurturing the institution of traditional, opposite-sex marriage ${ }^{67}$

Caution in defining a legislative term and preference for maintaining the status quo $^{68}$

Clinton-Signed Law "Unconstitutional", ABC News (Feb. 23, 2011, 12:39PM), http://abcnews.go.com/blogs/politics/2011/02/president-obama-instructs-justice-department-tostop-defending-defense-of-marriage-act-calls-clinton/ (reporting Obama declares section 3 of DOMA to be unconstitutional); see also Brief for United States on the Merits Question, United States v. Windsor, 133 S. Ct. 786 (2013) (No. 12-307) 2013 WL 683048 at "16 (solidifying Obama Administration's stance the Supreme Court should find section 3 of DOMA unconstitutional).

63. See Debra Cassens Weiss, Will Justices Opt for 'Offramps' in Same-Sex Marriage Cases? Standing Is One of the Issues, ABA J. (Dec. 10 2012, 8:41AM) http://www.abajournal.com/news/article/will_justices_opt_for_offramps_in_same-

sex_marriage_cases_standing_is_one_o/ (questioning whether the Supreme Court will decide the case on the sufficiency of Proposition 8 proponents' standing); see also Supp. Brief for Bipartisan Legal Advisory Group of the United States House of Representatives, United States v. Windsor, $133 \mathrm{~S} . \mathrm{Ct}$. 786 (2012) (No. 12-307) 2012 WL 5388782 (arguing House's sufficiency for standing).

64. See, e.g., Morrison v. Sadler, 821 N.E.2d 15, 30 (Ind. App. 2005) ("The State of Indiana has a legitimate interest in encouraging opposite-sex couples to enter and remain in, as far as possible, the relatively stable institution of marriage for the sake of children who are frequently the natural result of sexual relations between a man and a woman.").

65. See, e.g., Standhardt v. Super. Ct. ex rel. Cnty. of Maricopa, 77 P.3d 451, 461 (Ariz. Ct. App. 1st Div. 2003) ("Essentially, the State asserts that by legally sanctioning a heterosexual relationship through marriage, thereby imposing both obligations and benefits on the couple and inserting the State in the relationship, the State communicates to parents and prospective parents that their longterm, committed relationships are uniquely important as a public concern.").

66. See, e.g., Andersen v. King County, 138 P.3d 963, 982 (Wash. 2006) ("The State contends that procreation is a legitimate government interest justifying the limitation of marriage to opposite-sex couples.").

67. See, e.g., Kerrigan v. Comm'r. of Pub. Health, 957 A.2d 407, 476 (Conn. 2008) (preserving the traditional definition of marriage as a union between one man and one woman justifies prohibition on same-sex marriage according to defendant), But see, In re Marriage Cases, 183 P.3d 384, 402 (Cal. 2008) (" $[W]$ e cannot find that retention of the traditional definition of marriage constitutes a compelling state interest.").

68. See, e.g., In re Marriage Cases, 183 P.3d at 447-48 (arguing changes in the definition of marriage can only occur through the legislature or through the public exercising its initiative power); Kerrigan, 957 A.2d at $476 \mathrm{n} .78$ (characterizing the state's interest in prohibiting same-sex marriage as "an interest in maintaining the status quo out of respect for tradition"); Baker v. Vermont, 744 A.2d 864, 910 (Vt. 1999) (Johnson, J., concurring in part and dissenting in part) ("The State's objective is to preserve the status quo[.]"). 


\section{Caution in area of social divisiveness ${ }^{69}$ \\ Defending traditional notions of morality ${ }^{70}$ \\ Preserving scarce governmental resources ${ }^{71}$}

Courts have analyzed these reasons to see if they are supported by the law, have a factual basis, and are related to the ban on same-sex marriages. ${ }^{72}$ Some courts have even gone further and held full trials or evidentiary hearings on the state's proffered reasons for the bans, with the most extensive trial held by the Northern District of California regarding California's Proposition $8 .{ }^{73}$ Around the

69. See, e.g., Kerrigan 957 A.2d at 476 (justifying prohibition of same-sex marriage for the promotion of uniformity and consistency with the laws of other jurisdictions; Parker 0 . Hurley, 514 F.3d 87, 93 (1st Cir. 2008) (claiming from plaintiff that public schools are indoctrinating young children contrary to the parents' religious beliefs by informing students about same-sex relationships); see also Pew Res. Ctr., Different Attitudes on Society, N.Y. TIMES, June 22, 2012, http://www.nytimes.com/imagepages/2012/06/22/opinion/22leonhardtgph.html?ref=sunday (surveying societal attitude of gay marriage rights).

70. See, e.g., Baehr v. Lewin, 852 P.2d 44, 51-52 (Haw. 1993) (arguing that marriage laws embody the community's moral values); Andersen, 138 P.3d at 1034 (Bridge, J., concurring in dissent) (stating legislative intent of DOMA was to impose religious and moral restrictions on the institution of marriage as evidenced by legislative history).

71. See, e.g., Goodridge v. Dept. of Pub. Health, 798 N.E.2d 941, 964 (Mass. 2003) ("The third rationale advanced by the department is that limiting marriage to opposite-sex couples furthers the Legislature's interest in conserving scarce State and private financial resources.").

72. See, e.g., Morrison v. Sadler, 821 N.E.2d 15, 30-31 (Ind. Ct. App. 2005) ("Even accepting that many same-sex couples are successfully raising children in today's society, these couples are not at 'risk' of having random and unexpected children by virtue of their ordinary sexual activities. Extending the benefits of civil marriage to same-sex couples would not further the State's interest in 'responsible procreation' by opposite-sex couples. The differentiation between opposite-sex and same-sex couples in Indiana marriage law is based on inherent differences reasonably and rationally distinguishing the two classes: the ability to procreate "naturally." Given the high degree of deference we accord to legislative classifications, the Plaintiffs have not established that this particular classification violates the Equal Privileges and Immunities Clause of the Indiana Constitution, Article 1, \$ 23.").

See also Kerrigan 957 A.2d at 477-78 ("[B]eyond the mere assertion that uniformity and consistency with the laws of other jurisdictions represent a truly important governmental interest, the defendants have offered no reason why that is so, and we know of none. In the absence of such a showing, the defendants cannot prevail on their claim that the state's interest in defining marriage as most other jurisdictions do is sufficiently compelling to justify the discriminatory effect that that definition has on gay persons.... Although we acknowledge that many legislators and many of their constituents hold strong personal convictions with respect to preserving the traditional concept of marriage as a heterosexual institution, such beliefs, no matter how deeply held, do not constitute the exceedingly persuasive justification required to sustain a statute that discriminates on the basis of a quasi-suspect classification."); Andersen 138 P.3d at, 983 ("Under the highly deferential rational basis inquiry, encouraging procreation between opposite-sex individuals within the framework of marriage is a legitimate government interest furthered by limiting marriage to opposite-sex couples."); Andersen, 138 P.3d at 1027 (Bridge, J., concurring in dissent) ("What we ought not to address is marriage as the sacrament or religious rite - an area into which the State is not entitled to intrude at all and which is governed by articles of faith."); Standhardt v. Super. Ct. ex rel. Cnty. of Maricopa, 77 P.3d 451, 462 (Ariz. App. 1st Div. 2003) ("[T]he State's decision to permit all qualified opposite-sex couples to marry does not defeat the reasonableness of the link between opposite-sex marriage, procreation, and child-rearing."); Goodridge 798 N.E.2d at 964 ("An absolute statutory ban on same-sex marriage bears no rational relationship to the goal of economy.").

73. Perry v. Schwarzenegger, 704 F. Supp. 2d 921, 921-1004 (N.D. Cal. 2010). 
same time that lawsuits were filed challenging the constitutionality of marriage bans in various states and DOMA ${ }^{74}$, a state court in Miami-Dade, Florida held an extensive hearing on the constitutionality of Florida's ban on adoption by gay people. ${ }^{75}$ In its defense of the law, Florida put forth many of the same reasons that the states offered in the marriage cases. ${ }^{76}$

Both in the courts and through the political process, opponents of gay rights often made claims about how same-sex marriage hurts children. ${ }^{77}$ During the ballot initiative process, opponents of same-sex marriage effectively used a welldeveloped narrative that gay people are harmful to children in their campaign materials and commercials. ${ }^{78}$ The courts thoroughly vetted this narrative and rarely found any harm to children. ${ }^{79}$ One reason for these dramatically different results is that voters and judges evaluate and process communication differently. ${ }^{80}$

74. See, e.g., Perry, 704 F. Supp. 2d at 921; Windsor v. U.S., 797 F. Supp. $2 d 320$ (2011).

75. Fla. Dep't of Children \& Families v. Adoption of X.X.G., 45 So, 3 d 79 (Fla. Dist. Ct. App. 2010); FLA. STAT. ANN. \& 63.042(3) (West 2003) ("No person eligible to adopt under this statute may adopt if that person is a homosexual.").

76. Fla. Dep't of Children \& Families 45 So. 3d at 85-90 ("[T]he Department argues that there is a rational basis for the prohibition on homosexual adoption because children will have better role models, and face less discrimination, if they are placed in non-homosexual households, preferably with a husband and wife as the parents ... homes of homosexuals may be less stable and more prone to domestic violence... [homosexual parents] support adolescent sexual activity and experimentations ... placement of children with homosexuals presents a risk of discrimination and societal stigma."). Although this paper is mostly focused on marriage equality, many of the state's arguments about the potential harm to children in the Florida adoption case mirror the arguments most often made in the marriage cases.

77. See Part III \& IV, infra and accompanying notes.

78. See Part III \& IV, infra, and accompanying notes. Although the myth that gay people are harmful to children has been dispelled by psychologists and sociologists, the argument continues to be used in campaigns against marriage rights for same-sex couples. See Fla. Dept. of Children and Families 45 So. 3d at 94 ("[Florida Department of Children and Families] agrees that gay people and heterosexuals make equally good parents."); see also AM. PSYCHOLOGICAL Ass'N, LESBIAN \& GAY PARENTING 7 (2005), available at http://www.apa.org/pi/lgbt/resources/parenting-full.pdf ("Beliefs that lesbian and gay adults are not fit parents likewise have no empirical foundation[.]"); Position Statement on Homosexuality, AM. PSYCHIATRY ASs'N (Dec. 1992), available at http://www.psychiatry.org/advocacy - newsroom/position-statements ("Whereas homosexuality per se implies no impairment in judgment, stability, reliability, or general social or vocational capabilities[.]"); Corinna Vallianatos, Gay Parents' Right Backed, NAT'L Ass'N OF SOCIAL WORKERS (Jan. 2002), http://www.socialworkers.org/pubs/news/2002/01/gay.htm ("The overwhelming weight of authority has established beyond reasoned dispute that lesbian and gay parents are as capable of creating a healthy, loving and wholesome home environment for children as any other parents."); Gay Marriage Endorsed by American Academy of Pediatrics: 'It is in the best interests of their children', N.Y. DAILY NEWS (March 21, 2013, 11:06 AM), http://www.nydailynews.com/lifestyle/health/pediatricians-endorse-gay-marriage-healthy-kids-article-1.1294914 ("The nation's most influential pediatrician's group has endorsed gay marriage, saying a stable relationship between parents regardless of sexual orientation contributes to a child's health and well-being." ); Position Statement on Parenting of Children by Lesbian, Gay, and Bisexual Adults, CHILD WELFARE LEAGUE OF AM., http://www.cwla.org/programs/culture/glbtqposition.htm (Last visited Oct. 2, 2013) ("The Child Welfare League of America (CWLA) affirms that lesbian, gay, and bisexual parents are as well suited to raise children as their heterosexual counterparts.").

79. See Part IV.A, infra.

80. See Part IV, infra. 


\section{THE NARRATIVE PARADIGM: A COMMUNICATION THEORY FOR EVALUATING Public MORAL ARguMENTS}

Walter Fisher, a professor at the University of Southern California, developed a communications theory called the "narrative paradigm," which is very helpful in understanding the differences in the way experts and lay people evaluate communication. ${ }^{81}$ Specifically, it is instructive in understanding how judges and voters have analyzed arguments involving same-sex marriage.82 Fisher's paradigm rests on the idea that all communication is a form of storytelling, and humans understand life as a series of ongoing narratives. ${ }^{83} \mathrm{He}$ believes that people process information through using "good reasons" that are shaped by history, culture, biography, and character. ${ }^{84}$

Fisher contrasts this theory with what he labels the rational-world paradigm, where people communicate and argue through reason and logic. ${ }^{85}$ Fisher suggests that for centuries, most scholars have subscribed to the view that humans have a rational view of the world. His paradigm challenges the view that:

[H]uman communication-if it is to be considered rhetorical-must be an argumentative form, that reason is to be attributed only to discourse marked by clearly identifiable modes of inference and/or implication, and that the norms for evaluation of rhetorical communication must be rational standards taken essentially from informal or formal logic. ${ }^{86}$

\section{A. The Rational-World Paradigm}

In detailing the rational-world paradigm, Fisher posits that most scholars believe that: humans are essentially rational; humans make decisions and communicate using reason and logic; ways of communicating differ from field to field (i.e., legal, scientific, public, political, etc.); rationality requires subjectmatter knowledge, persuasive ability, and skills at using general rules of advocacy; and the world is a set of "logical puzzles which can be resolved through appropriate analysis and application of reason conceived as an argumentative construct." 87

81. Fisher, Human COMMUNICATION, supra note 16, at 59-60, 72-73. See also Walter R. Fisher, Narration as a Human Communication Paradigm: The Case of Public Moral Argument, 51 CoMMC'N MONOGRAPHS 1 (1984) [hereinafter Fisher, Paradigm]. Fisher also responded to criticisms and elaborated on his paradigm. See Walter R. Fisher, The Narrative Paradigm: An Elaboration, 52 CoMMC'N MONOGRAPHS 347 (December 1985) [hereinafter Fisher, Elaboration]; Walter R. Fisher, Clarifying the Narrative Paradigm, 56 COMMC'N MONOGRAPHS 55 (March 1989) [hereinafter Fisher, Clarifying]. For good summary of the paradigm, see Alan Bean, Stories We Believe in: Learning from Walter Fisher's Narrative Paradigm, FRIENDS OF JUSTICE, http:/ / friendsofjustice.wordpress.com/2011/02/24/storieswe-believe-in-learning-from-walter-fishers-narrative-paradigm/ (last visited. Oct. 2, 2013).

82. See Part IV, infra.

83. FISHER, HUMAN COMMUNICATION, supra note 16 , at 64 .

84. FISHER, HUMAN COMMUNICATION, supra note 16, at 105-23; Fisher Paradigm, supra note 81, at $7-8$.

4 .

85. FISHER, HUMAN COMMUNICATION, supra note 16, at 59-60; Fisher Paradigm, supra note 81, at

86. Fisher, Paradigm, supra note 81 , at 2.

87. FISHER, HUMAN COMMUNICATION, supra note 16, at 59-60; Fisher Paradigm, supra note 81, at 
Fisher views the rational-world paradigm as too limiting and only effective for those who are in their fields, as it requires a citizenry that "shares a common language, general adherence to the values of the state, information relevant to the questions that confront the community to be arbitrated by argument, and an understanding of argumentative issues and various forms of reasoning and their appropriate assessment," which he thinks is unrealistic because most people are not trained or educated in this logical process. ${ }^{88}$ Fisher does not discount that people use systems of formal logic and reasoning, but rather posits that those in positions of power, or those with the requisite knowledge and authority, control these systems. ${ }^{89}$ Instead, Fisher believes that lay people use values and "good reasons" in making decisions and choosing to be persuaded by others. ${ }^{90}$

\section{B. The Components of the Narrative Paradigm}

Fisher argues that the narrative paradigm encompasses all communication and should be considered a "metaparadigm." 91 He bases his narrative paradigm on five basic assumptions. ${ }^{92}$ First, humans are generally storytellers. Second, human decision-making and actions are based on "good reasons." 93 Third, these good reasons flow from a person's own understanding, experiences, and views of history, biography, culture, and perceptions of others. ${ }^{94}$ Fourth, humans will judge the stories using narrative rationality..$^{95}$ This rationality is based on the person's "inherent awareness of narrative probability," or whether the story is coherent. Rationality is based also on the person's "constant habit of testing narrative fidelity, whether the stories they experience ring true with the stories that they know to be true in their lives." Finally, the world is a set of stories that the person picks to match his or her values and beliefs. ${ }^{96}$

Fisher also suggests that people focus on narrative rationality when evaluating political communication: "communication through the perspective of narrativity is to focus on message, on the individuated forms that constitute it, and on the reliability, trustworthiness, and desirability of what is saidevaluated by using the tests of narrative rationality." 97 In this sense, narrative rationality is different from traditional rationality because it is "not an account of the 'laws of thought' and it is not normative in the sense that one must reason according to the prescribed rules of calculation or inference making." ${ }^{98}$ Instead,

4 .

88. Fisher, HUMAN COMMUNICATION, supra note 16, at 59-60; Fisher, Paradigm, supra note 81, at 4 .

89. FISHER, HUMAN COMMUNICATION, supra note 16 , at 60 .

90. $I d$. at 64-65.

91. Fisher, Elaboration, supra note 81, at 347. See also FISHER, HUMAN COMMUNICATION, supra note 16, at 2,59 ("The narrative paradigm does not deny reason and rationality; it reconstitutes them, making them amenable to all forms of communication").

92. FISHER, HUMAN COMMUNICATION, supra note 16, at 64 .

93. Id.

94. Id.

95. Id.

96. Id.

97. Id., at 148 .

98. Fisher, Paradigm, supra note 81 , at 9. 
narrative rationality is descriptive and provides an understanding of "human choice and action." 99

Fisher does not argue that the narrative paradigm replaces the rationalworld paradigm, but that traditional rationality is best used in specialized fields, and even in those fields, the narrative paradigm is instructive. ${ }^{100}$ The rationalworld paradigm focuses on how logic and reason are used to evaluate rhetoric and communication; the narrative paradigm focuses on how communication is evaluated based on morality, values, and the person's own life experiences. ${ }^{101}$ Fisher essentially separates discourse used in specialty areas between experts, like lawyers and judges, and the discourse used between ordinary people, especially in debates about public morality like marriage equality. ${ }^{102}$ The parties debating marriage rights for same-sex couples also have used experts to provide reasoning and support to their arguments, an appropriate role for experts in public moral debates according to Fisher. ${ }^{103}$

\section{Using Narrative Rationality to Determine Which Narratives to Adopt as True}

In contrast to the rational-world paradigm, Fisher believes that people evaluate information and communication by choosing the stories that they find most legitimate. ${ }^{104}$ Under his paradigm, people choose to believe stories that "ring true to the stories they know to be true in their lives," 105 a process he labels as narrative rationality. ${ }^{106} .107$

In determining whether a story has narrative probability, people will decide if it is coherent and makes sense to them. For example, many of the political arguments made about gay rights have been structured to appear coherent to voters, as they often played into what people already knew about gay people. ${ }^{108}$ Fisher further suggests that people are more likely to believe a story if it has narrative coherence, structural coherence, material coherence, and character coherence. $109^{109}$ For narrative coherence, people evaluate whether the story is

\footnotetext{
99. Id.

100. Fisher, Paradigm, supra note 81, at 10; FISHER, HUMAN COMMUNICATION, supra note 16, at 73.

101. FISHER, HUMAN COMMUNICATION, supra note 16, at 71-73 ("Public moral argument needs to be distinguished from reasoned discourse in interpersonal interactions and from arguments occurring in specialized communities, such as theological disputes, academic debates, and arguments before the Supreme Court.").

102. $I$ Id.

103. Fisher, Paradigm, supra note 81, at 13; FISHER, HUMAN COMMUNICATION, supra note 16, at 73. For an example of how the opponents of marriage equality integrated experts to support their underlying message, see infra notes 321-23 and accompanying text.

104. FISHER, HUMAN COMMUNICATION, supra note 16, at 64 . See also Terry Mills, Listening from the Sidelines: The Telling and Retelling of Stories by Centenarians, 27 GENERATIONS, Fall 2003, at 16-17.

105. Fisher, Paradigm, supra note 81 , at 9 . See also Mills, supra note 104, at 17.

106. Fisher, Paradigm, supra note 81, at 9.

107. Fisher, HUMAN COMMUNICATION, supra note 16, at 47. See also, J. Christopher Rideout, Storytelling, Narrative Rationality, and Legal Persuasion, 14 LEGAL WRITING: J. LEGAL WRITING INST. 53, 63-66 (2008) (discussing narrative probability and narrative rationality, with a focus on when a story is coherent).

108. For a discussion about how the arguments against gay rights was coherent to the general public, see infra notes 187-193 and accompanying text.

109. FISHER, HUMAN COMMUNICATION, supra note 16, at 47.
} 
consistent. ${ }^{110}$ For structural coherence, people evaluate whether the parts of the story flow and fit together. ${ }^{111}$ For material coherence, the person looks for congruence between this story, other stories, and information that he already knows. For character coherence, people evaluate whether the character of the story is believable and acts consistently with what is in the story and what people already know of him. ${ }^{112}$

In determining whether the story has narrative fidelity, people will examine the components of the story to see if they constitute "good reasons for belief or action." 113 In developing the concept of narrative fidelity, Fisher explains that humans "as rhetorical beings are as much valuing as they are reasoning animals." 114 Fisher believes that people will constantly make value judgments in making decisions and that this process is not irrational. ${ }^{115}$ As such, he believes that people will not only use traditional forms of logic to determine "good reasons" for their decision-making, or what he called "the logic of reasons," but will focus more on using the "logic of good reasons" in assessing the narrative fidelity. In Fisher's view, the traditional "logic of reasons" asks the following questions:

Are the statements of facts really factual?

Have any relevant facts been omitted or distorted?

What types of reasoning are used?

Are the arguments relevant, and do they cover all of the arguments needed to assess the statement?

Does the statement address the "real" issues in the case?116

Meanwhile, Fisher's "logic of good reasons" imbeds values in the process to ask these questions:

What are the implicit and explicit values embedded in the narrative?

Are the values appropriate and relevant to the decision?

What are the consequences of adhering to the narrative's values?

Are the values confirmed and validated by our experiences?

Are the values the ideal basis for ideal human conduct? ${ }^{117}$

Fisher does not believe that the evaluation of these value questions in the process of determining good reasons is a fault of his theory, but that these questions simply recognize the nature of human communication and the

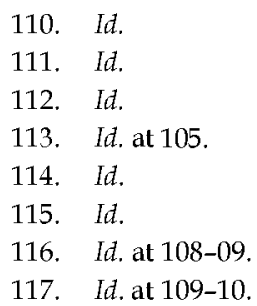


importance of values in decision-making. ${ }^{118}$

The contrast between the narrative paradigm and the rational-world paradigm is clear when analyzing the moral debate involving gay rights. Where the public has discussed gay issues and same-sex marriage using moral terms based on their culture, history, religion, and moral system, ${ }^{119}$ lawyers and judges generally develop and analyze arguments using legal reasoning and logic. ${ }^{120}$ Because the public debate on gay rights has often centered on what "feels right" to each person, ${ }^{121}$ reason and logic have not always played a central role, allowing gay rights opponents to effectively focused their arguments around the safety of children. ${ }^{122}$

\section{THE DEVELOPMENT AND CONTINUED USED OF THE NARRATIVE THAT GAYS AND LESBIANS ARE HARMFUL TO CHILDREN}

Fisher's theory is instructive in understanding how people have come to define gay people over a large part of the past few decades. Fisher believes that his paradigm is most informative when dissecting public moral arguments because they tend to involve the general public and not just a group of experts, so a debate about homosexuality is a perfect example of the narrative paradigm at work. ${ }^{123}$

Opponents of gay rights began defining gay people in the 1970s, when little was known about gay people, and most of the "information" about gay people was negative. ${ }^{124}$ With little known about gays and lesbians, gay rights opponents

118. $I d$. at 109. Fisher clarified what narrative rationality means: "Narrative fidelity concerns the 'truth qualities' of the story, the degree to which it accords the logic of good reasons: the soundness of its reasoning and the value of its values. To test soundness, one may, when relevant, employ standards from formal or informal logic. Fisher, Elaboration, supra note 81, at 349-50.

119. Melinda S. Miceli, Morality Politics us. Identity Politics: Framing Processes and Competition among Christian Right and Gay Social Movement Organizations, 20 SOC. F. 589 (2005) ("In general, gay rights groups engage in framing strategies centered firmly in the arena of identity politics ... while Christian Right organizations generally implement framing strategies situated within the context of morality politics.").

120. Michael Smith, Advanced Legal Writing: Theories and Strategies in Persuasive WRITING 23 (2d Ed, 2008).

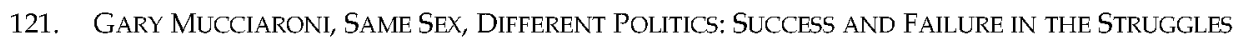
OVER GAY RIGHTS 23-24 (2009) ("The 'ick factor' reflects the taboo of gay sex, much of it fed by centuries of religious injunctions against sexual conduct between same-sex partners. Further normalizing gay relationships by legalizing their marriages, adoptions, and sexual behaviors may encourage gay couples to "flaunt" their sexuality by engaging in public displays of affection.").

122. See Part III, supra.

123. FISHER, HUMAN COMMUNICATION, supra note 16, at 79-80 (stating that public moral argument is "made available for wide consumption" and is aimed at "untrained thinkers.").

124. FRed FeJES, GAY Rights and MORAL PANIC: THE ORIGINS OF AMERICA'S Debate ON HOMOSEXUALITY 11-52 (2008) (detailing the media depictions of gay people from 1940 through 1970 which often depicted gay people as sick, perverted, and sad). Most people consider the modern gay rights movement to start with the Stonewall riots in New York City in June 1969, leading more gays and lesbians out of the closet in many large metropolitan areas and progressive college towns in the United States. LINAS ALSENAS, GAY AMERICA 86-88 (2008). Subsequently, gay rights advocates had a major victory in 1973 when the American Psychiatric Association removed homosexuality from its list of mental disorders. See Report of the American Psychological Association Task Force on Appropriate Therapeutic Responses to Sexual Orientation, Am. Psychological Ass'n (2009), 
were able to develop their own narrative that denying gay rights will protect children, often equating homosexuality with pedophilia and arguing that schools would have to teach children that homosexuality is the moral equivalent of heterosexuality. ${ }^{125}$ In fact, the first organization to stop a gay rights ordinance was called "Save Our Children," 126 which argued that gays molest children and that they need to recruit children to keep the gay community alive. ${ }^{127}$

The rhetoric from this highly publicized campaign of gay rights opponents was the first public step in defining the relationship between gays and children. ${ }^{128}$ The narrative was cemented into our collective psyche through the very visible HIV/ AIDS crisis of the 1980s, the debate on the Boy Scouts' policy of excluding gays, the emergence of the Moral Majority and its "experts", and the widespread public outcry over the Catholic Church's molestation scandals. ${ }^{129}$

\section{A. The Initial Framing of the Narrative: Early Political Campaigns Against Gay Rights}

The portrayal of gays and lesbians in the media was never very positive prior to the $1970 \mathrm{~s}, 130$ and gay rights were generally advanced at the local level in largely progressive communities. ${ }^{131}$ In fact, many media messages during the 1950 s and 1960s were based on negative stereotypes about gays and lesbians, with a very prominent focus on gay men as sexual predators. ${ }^{132}$

It was not until 1977 that the issue of gay rights became so prominent nationally and in the media, ${ }^{133}$ with a highly publicized debate about a local antidiscrimination law being considered in Dade County Florida (now known as

http://www.apa.org/pi/lgbt/resources/therapeutic-response.pdf (last visited Oct. 3, 2013).

125. See Part III, supra.

126. Anita Bryant, The ANita Bryant Story: The Survival of OUR Nation's Families and THE THREAT OF MiLITANT HOMOSEXUALITY 12 (1977).

127. See CLENDINEN \& NAGOURNEY, supra note 31, at 303-05 (detailing the arguments that the "Save Our Children" organization used in its campaign materials).

128. I do not mean to overstate the use of the children protection arguments, because several different arguments have been successful with different gay rights issues. See, e.g., Samuel A. Marcosson, The "Special Rights Canard" in the Debate over Lesbian and Gay Civil Rights, 9 NOTRE DAME J.L. ETHICS \& PUB. POL'Y 137 (1995) (discussing the use of the argument that providing antidiscrimination protections to gays and lesbians give them special rights). I do argue, however, that the children protection argument has been consistently part of the debate even when it was not central to the anti-gay rights movement's rhetoric.

129. See Part IV.A, infra.

130. FEJES, supra note 124, at 11-52 (discussing the history of the depiction of gays and lesbians before 1970).

131. Many cities began passing anti-discrimination laws in the 1970s. FEJES, supra note 124, at 53; ALSENAS, supra note 124, at 103.

132. See, e.g., The Homosexual, YOUTUBE (DEC. 30, 2008), http://www.youtube.com/watch? $v=\mathrm{dXYnEobD} 0 \mathrm{k}$ (A video developed by the Inglewood, CA police department to tell boys to stay away from gay men because they prey on young boys.).

133. I do not want to diminish the importance of many very public events that occurred before the Dade County ordinance repeal in 1977, including the Stonewall Riots, the removal of homosexuality as a disorder by the American Psychological Association, or the passage of gay rights ordinances in some cities. Instead, the push to repeal the Dade ordinance became the first national debate on gay rights and likely received the most attention of any initiative to limit or eliminate gay rights. 
Miami-Dade County). ${ }^{134}$ In response to the new ordinance, Anita Bryant, ${ }^{135}$ a high-profile entertainer who had been Miss Oklahoma and second-runner-up to Miss America, began a campaign to overturn the ordinance. ${ }^{136}$ Because of her fame, ${ }^{137}$ she became one of the first public figures to raise the profile of the gay rights debates that previously had been fought mostly locally. ${ }^{138}$ A 1970 s poll showed that $70 \%$ of the American public recognized her. ${ }^{139}$ With her fame and deeply-held religious views, ${ }^{140}$ she began a public campaign that demonized gays and lesbians, making both religious and secular arguments. ${ }^{141}$

Bryant began her fight when the commission first considered the new ordinance. ${ }^{142}$ A self-proclaimed Christian, Bryant first focused on the moral problems with homosexuality, using the Bible to support her claims. ${ }^{143}$ Knowing that she could not simply rely on quoting the Bible and demonizing gays, ${ }^{144}$ she also developed a message that was both secular and promoted a goal that would be uniformly accepted-that nothing should be done to harm children. ${ }^{145}$ As Professor William Eskridge stated, her "fantastic claims [that gays would harm children] preyed on mothers' concerns for their children, as well as men's antihomosexual prejudices." 146 For example, to persuade the commission against

134. See infra notes 143 to 168 , and accompanying text.

135. Anita Bryant became the first famous anti-gay rights advocate. She was a former Miss America who felt it was her religious duty to fight against gay rights, most notably in Miami and all across Florida. Much of her rhetoric focused on the harm gay rights would have on children. BRYANT, supra note 126, at 13-15 (1977). See also FEJES, supra note 124, at 94; CLENDINEN \& NAGOURNEY, supra note 31, at 299.

136. See BRYANT, supra note 126. See also William N. Eskridge, Jr., Body Politics: Lawrence v. Texas and the Constitution of Disgust and Contagion, 57 FLA. L. REV. 1011, 1015-21 (2005) (detailing the Anita Bryant campaign to overturn the Dade County ordinance). Prof. Eskridge gives an excellent account of the rhetoric Ms. Bryant's campaign used during her fight to overturn the Dade County gay rights law and to prevent gays from adopting children and becoming teachers in Florida. He describes how the tactics used by her campaign helped develop a "Constitution of Anti-Homosexual Disgust and Contagion" that "tolerates a body politics that trades on appeals to disgust and contagion." Id. at 1013-14.

137. Anita Bryant had three big pop songs: "Till There Was You" (1959); "Paper Roses" (1960) (successfully covered 13 years later by Marie Osmond); and "In My Little Corner of the World" (1960). She became a spokeswoman for the Florida Citrus Commission in 1969, and nationally televised commercials featured her famous saying: "A day without orange juice is like a day without sunshine". She sang "The Battle Hymn of the Republic" during the graveside services for Lyndon Johnson in 1973 and performed the National Anthem at Super Bowl III in 1969. See Eskridge, supra note 136, at 1015; Thomas C. Tobin, Bankruptcy, Ill Will Plague Bryant, ST. PETERSBURG TIMES (April 28, 2002), http://www.sptimes.com/2002/04/28/State/Bankruptcy_ill_will_.shtm1.

138. Eskridge, supra note 136, at 1015-16

139. Id. at 1015 .

140. She often stated that gays were "abnormal" and "vile beastly creatures". BRYANT, supra note 126, at 13-15 ("I express the valid fears we now felt of widespread militant homosexuals' efforts to influence their abnormal way of life"); Eskridge, supra note 136, at 1017 (2005) (quoting PERRY DEANE YOUNG, GOD'S BULliES: NATIVE REFLECTIONS ON PREACHERS AND POLITICS 44 (1982), which states that she compared gays to Sodom and Gomorrah and called them vile).

141. See BRYANT, supra note 126 , at 141-48.

142. FEJES, supra note 124 , at $80-81$.

143. Id. at 80 .

144. Id. at 80-82.

145. Id.

146. See Eskridge, supra note 136, at 1017. 
passing the anti-discrimination law in the first place, she wrote a letter to each commissioner stating that if they passed the new law, they "would be discriminating against my children's right to grow up in a healthy, decent community that [they are] proud to be part of." 147 When she later spoke in front of the commission, she said that she spoke as a "wife and a mother" and that she would do everything she could "to insure that [her children] have the right to a healthy and morally good life." 148

Even after Bryant's moral and emotional pleas to the commission, they approved the new ordinance. ${ }^{149}$ Bryant then began an effort to repeal the law. ${ }^{150}$ Armed with the necessary petitions to put a referendum overturning the antidiscrimination law on the ballot, Bryant helped start the organization "Save Our Children," which developed its arguments around protecting children. ${ }^{151}$ To show that gays harm children, the "Save Our Children" campaign used four basic arguments: gay men recruit children because they cannot have children of their own, they want to teach children that homosexuality is acceptable, they cause physical harm to others, and they seduce and molest children. ${ }^{152}$

A typical argument about how gay people recruit children appeared in one of the "Save Our Children" campaign's advertisements, which appeared in Miami newspapers:

This recruitment of our children is absolutely necessary for the survival and growth of homosexuality -for since homosexuals cannot reproduce, they must recruit, must refresh their ranks. And who qualifies as a likely recruit: a 35-year old father or mother of two... or a teenage boy or girl who is surging with sexual awareness? (The Los Angeles Police Department recently reported that 25,000 boys 17 years old or younger in that city alone have been recruited into a homosexual ring to provide sex for adult male customers. One boy, just 12 years old, was described as a $\$ 1,000$-a-day prostitute. ${ }^{153}$

Another advertisement stated that passing a gay rights law would show that it is acceptable and even possibly preferable to be gay:

What these people really want, hidden behind the obscure legal phrases is the legal right to propose to our children that there is an acceptable alternate way of life. No one has a human right to corrupt out children. Prostitutes, pimps and drug pushers, like homosexuals, have civil rights, too, but they do not have the right to influence our children to choose their way of life. Before I yield to this insidious attack on God and his laws, and parents and their right to protect their children, I will lead such a crusade to stop it as this country has not seen before. ${ }^{154}$

Arguments that gays are dangerous were most clearly stated by the Rev.

\footnotetext{
147. BRYANT, supra note 126 , at 16 .

148. Id. at 24-25.

149. FEJES, supra note 124 , at 82 . The vote was 5-3.

150. Id. at $93-95$.

151. BRYANT, supra note 126, at 141-48; FEJES, supra note 124, at 80-82.

152. See infra notes 162 to 170 , and accompanying text.

153. BRYANT, supra note 126 , at 146.

154. See CLENDINEN \& NAGOURNEY, supra note 31, at 292.
} 
Jerry Falwell, who appeared at a rally in support of Bryant's efforts: "So-called gay folks [would] just as soon kill you as look at you." 155

The most prevalent arguments made by "Save Our Children" focused on how gay men were sexual predators who were waiting to seduce, molest, and ultimately recruit young boys. ${ }^{156}$ For example, an advertisement published the day before the referendum election included the headline: "Other Side of the Homosexual Coin is a Hair-Raising Pattern of Recruitment and Outright Seduction and Molestation." 157 The same advertisement included pictures of newspaper clippings detailing stories of teachers and gay men arrested for having sex with children. ${ }^{158}$ During the campaign, Bryant told the story of a school principal in a suburban Miami city who was arrested on "homosexualrelated charges" that eventually produced photos of "ten-and eleven-year old boys in homosexual relationships with older men." 159 Bryant also would argue that legitimating homosexuality would usurp parents" "rights to raise spiritually sound, God-fearing heterosexual children and provide homosexuals a green light to recruit and molest their children in schools, public bathrooms, and elsewhere, and force religious schools, churches, and synagogues to hire individuals who partake in activities that they deem 'as unnatural and deviant." $160 \mathrm{~A}$ "Save Our Children" brochure listed the "demands. . from the February 1972 platform of A National Coalition of Gay Organizations in Chicago," which all focused on children: "[r]epeal of the laws governing the age of consent, [f]ederal support for sex education courses. . .presenting homosexuality as a valid, healthy preference and lifestyle, [e]nactment of legislation so that child custody, adoption, visitation rights, foster parenting, and the like shall not be denied because of sexual orientation." 161 All of these materials appealed to the parents' desire to protect their children, depicted gay men as predatory, and based their arguments in fear to motivate voters.

Meanwhile, the campaign opposing the referendum (and supporting the underlying anti-discrimination ordinance) focused mostly on a human-rights theme. ${ }^{162}$ The group later decided to confront the claims that gay people harm children, but they rebutted these charges too late in the election to have any

155. See Eskridge, supra note 136, at 1017; CLENDINEN \& NAGOURNEY, supra note 31, at 306.

156. SAVE OUR CHILDREN, INC., SAVE OUR CHILDREN FROM HOMOSEXUALITY! (1977), available at http://insight2,library,cornell,edu:8280/luna/servlet/detail/CORNELL 10 1 64932 110438:Saveour-children-from-homosexuality.

157. See CLENDINEN \& NAGOURNEY, supra note 31, at 304 (quoting the advertisement that appeared in the Miami Herald on June 6, 1977).

158. Id.

159. BRYANT, supra note 126 , at 125 .

160. As reprinted in Sylvia R. Lazos Vargas, Judicial Review of Initiatives and Referendums in which Majorities Vote on Minorities' Democratic Citizenship, 60 OHIO ST. L.J. 399, 431 (1999) (quoting D. Jason Berggren, Responding to the Spirit of Stonewall: Righteous Referendums, Ecumenism and the Anti-Gay Rights Politics of the Christian Right (1995) (unpublished M.A. thesis, Florida State University) (on file with the Florida State University Library).

161. SAVE OUR CHILDREN, INC., SAVE OUR CHILdREN FROM HOMOSEXUALITY! (1977), available at http:/ insight2,library,cornell,edu:8280/luna/servlet/detail/CORNELL 10 1 64932 110438:Saveour-children-from-homosexuality.

162. FEJES, supra note 124 , at 139. 
impact. ${ }^{163}$ Bob Kunst, an early leader for the coalition fighting against the referendum, also focused heavily on how the underlying ordinance helped protect sexual freedom, something many thought helped support Bryant's claim that gay rights hurt children. ${ }^{164}$ Eventually, Kunst and his supporters left the main coalition to work on their own campaign to fight against the referendum. ${ }^{165}$ As a result, opponents of the referendum had two different and ineffective themes: one about protecting human rights and one about protecting sexual freedom. ${ }^{166}$ With the high-profile campaign that focused on the highly emotional issue of protecting children and the immorality of homosexuality, "Save Our Children" overwhelmingly won the election with $69 \%$ of the vote and successfully caused the anti-discrimination ordinance to be repealed. ${ }^{167}$

When viewed through Fisher's paradigm, it is clear why the narrative that gay people harm children "rang true" to voters while voters did not respond to the abstract themes of human rights and sexual freedom. ${ }^{168}$ Because the gay rights movement was just developing in the 1970s, it had no unifying message that resonated with the public. ${ }^{169}$ Gay people were just becoming open about their sexuality, so it was generally difficult for them to respond collectively or individually to these charges. ${ }^{170}$ Furthermore, the concept of gays and lesbians having children was a very new concept and unfamiliar to the general public. ${ }^{171}$ As was done in the Dade County election, gay rights activists across the country often focused on human rights and sexual freedom themes, ${ }^{172}$ but neither of these themes could be told through stories that were relatable, so they lacked any narrative rationality with voters. ${ }^{173}$ A typical parent would have had "good reasons" to reject the gay rights activist's theme of promoting sexual freedom because it did not align with their values at the time and likely seemed much less

163. Id. Many people argued that a major mistake in trying to fight the referendum was not countering the harm-to-children argument until it was too late to change people's views about homosexuality. Id. See also, CLENDINEN \& NAGOURNEY, supra note 31, at 305.

164. FEJES, supra note 124, at 136. Fejes also details how Kunst was involved in helping pass the original non-discrimination ordinance and how his main purpose in supporting the ordinance was his strong interest in human liberation and expanding the idea of sexuality. Id. at 67-71.

165. CLENDINEN \& NAGOURNEY, supra note 31 , at 301 .

166. Id. at 119 .

167. Id. at 144 (explaining that the ordinance was repealed by a vote of $69.3 \%$ to $30.6 \%$ ).

168. CLENDINEN \& NAGOURNEY, supra note 31, at 301 (discussing how Kuntz's message focused on sexual freedom and the others wanted to focus on human rights).

169. Id.

170. William N. Eskridge, Jr., Challenging the Apartheid of the Closet: Establishing Conditions for Lesbian and Gay Intimacy, Nomos, and Citizenship, 1961-1981, 25 HOFSTRA L. ReV. 817, 821-26 (1997) (discussing how the period of 1961-1981 represented a huge shift within the gay community with more gays and lesbians coming out of the closet and becoming more visible).

171. For an overview of the history and development of same-sex parenting rights, see Ruthann Robson, Our Children: Kids of Queer Parents \& Kids Who Are Queer: Looking at Sexual Minority Rights from a Different Perspective, 64 ALB. L. REV. 915 (2001); Nancy D. Polikoff, Lesbian and Gay Parenting: The Last Thirty Years, 66 MONT. L. REV. 51 (2005).

172. See supra notes $162-167$, and the accompanying text.

173. See CLENDINEN \& NAGOURNEY, supra note 31, at 307 (describing how many voters viewed gay people with disdain after all of the campaigning, often stating that they didn't want Miami to turn into another San Francisco, which was described as a "cesspool of sexual perversion"). 
important than protecting their children. ${ }^{174}$ Furthermore, including the concept of sexual freedom in the fight for gay rights seemed more focused on the individual instead of the collective, a concept that ran counter to the broader values of family. ${ }^{175}$ It was easy for voters to choose between protecting their children or promoting sexual freedom for a group of people who were generally unfamiliar to or disliked by most of their fellow constituents. ${ }^{176}$

The civil rights theme presented by those fighting for gay rights also did not resonate with the voters because it lacked narrative coherence or fidelity. The civil rights struggles of African-Americans was still fresh in voters' minds. ${ }^{177}$ It was probably difficult for people to see how gay rights fit into that struggle, so the story lacked structural coherence. ${ }^{178}$ At that time, most people equated homosexuality with the act of sex and thought being gay was a choice, whereas being African-American was viewed as immutable, so the argument also lacked narrative fidelity to voters. ${ }^{179}$

174. As Fisher outlines in his description of narrative rationality, people generally accept stories using good reasons. These "good reasons" focus on whether the values imbedded in the story are consistent with one's values and whether accepting these values would be an "ideal basis for human conduct." FISHER HUMAN COMMUNICATION, supra note 16, at 109.

175. Ann Ferguson, Gay Marriage: An American and Feminist Dilemma, HYPATIA, Winter 2007, at 39-40:

The national identity, the "American way of life," is portrayed as so dependent on our intimate sexual and reproductive choices that private life must be made a public political issue, and wrong choices here are seen to undermine our national identity. Those supporting right-wing "family values" from the Reagan era forward have perpetuated the fantasy that the patriarchal heterosexual family, where abortion never occurs, is basic for a healthy national identity, and that allowing single motherhood, lesbian and gay marriage, and reproductive choice will lead to chaos and disorder that will weaken our nation.

176. See CLENDINEN \& NAGOURNEY, supra note 31 , at 307.

177. The assassination of Martin Luther King occurred less than one decade before the referendum in Miami-Dade. See Tony Capaccio, After Martin Luther King's 1963 Speech, FBI Began Spying on Cizil Rights Leader, WASH. POST (August 27, 2013), http://articles.washingtonpost.com/2013-08-27/politics/41497170_1_speech-surveillance-programintelligence-activities.

178. See Margaret M. Russell, Lesbian, Gay and Bisexual Rights and "The Civil Rights Agenda", 1 AFR.-AM. L. \& POL'Y REP. 33 (1994) (describing the hostility that some have toward drawing similarities between the African-American civil rights movement and the gay rights movement). But see Evan Wolfson, Civil Rights, Human Rights, Gay Rights: Minorities and the Humanity of Different, 14 HARV. J.L. \& PUb. POL'Y 21 (1991). Some continue to debate whether the push for gay rights fits under the broader civil rights movement. See, e.g., JONATHAN GOLDBERG-HILLER, THE LIMITS TO Union: SAME-SEX MARRIAGE AND the POlitics OF CIVIL Rights 46 (2004) (describing how some believe that gay rights activists are incorrectly drawing parallels with the experiences of AfricanAmericans).

179. Although the ordinance was protecting against discrimination, which aligns with the rights sought during the civil rights movement that led to Title VII of the Civil Rights Act, most people viewed sexual orientation in terms of a sexual act and not an identity. D. GARTH TAYLOR \& TOM W. SMITH, Public Opinion Regarding VARIOUS Forms of SEXUAL BEHAVIOR, (1978) (finding that almost seventy percent of people in 1978 thought that homosexual acts were immoral); Mary Riege Laner \& Roy H. Laner, Personal Style Or Sexual Preference: Why Gay Men Are Disliked, 9 INT'L REV. MODERN SOC. 215 (1979) (discussing the various reasons why gay men were viewed so unfavorably during the 1970s). For a discussion on the early development of the distinction between the sexual act and sexual orientation identity, see Janet E. Hailey, Reasoning about Sodomy: Act and Identity in and After Bowers v. Hardwick, 79 VA. L. REV. 1721 (1993). Even the famous slogan "Gay is Good," which was not the focus of the Dade County election, was not widely accepted by the public because few people 
Meanwhile, voters in the 1970s likely thought the campaign theme that gay people may harm children had narrative probability. Telling voters that gay people were harmful to children was coherent at the time, both structurally and materially. ${ }^{180}$ Because not much was known about homosexuality before this public campaign, and what was known was not positive, ${ }^{181}$ Bryant and her colleagues were able to define gay and lesbian people in a negative light. ${ }^{182}$ For example, when an advertisement from the "Save Our Children" campaign highlighted the vulnerability of children, the idea that children could be recruited or harmed by gay people likely "rang true" to most voters. ${ }^{183}$ Also, the campaign used newspaper stories to support its claims that gay people molest children, so Bryant's claims were consistent with what voters were hearing from reputable sources like the Miami Herald. ${ }^{184}$ As such, the argument that gay people could harm children seemed more in line with what voters already knew and thought about homosexuality, ${ }^{185}$ in strong contrast to the messages coming out of the gay rights campaigns. ${ }^{186}$

The argument that gay people were harmful to children also had narrative fidelity with voters. The argument that the proponents of the referendum advanced was laden with values, specifically those regarding children, sexual morality, religion, and the health and safety of families. ${ }^{187}$ Society has a strong history of valuing children more than almost anything, ${ }^{188}$ and the media and culture of the 1970s focused heavily on parents' love for their children, as seen on televisions shows like Happy Days and The Waltons. ${ }^{189}$ Because it was framed around protecting children, the referendum's proponents' message resonated

had any familiarity or positive association with gay people, so the narrative also lacked fidelity. See VERN L. Bullough, BEFORE STONEWALL: ACTIVISTS FOR GAY AND LESBIAN RigHTS IN HistoriCAL CONTEXT 209-18 (2002) (discussing how Frank Kameny coined the phrase "gay is Good" in response to being fired by the federal government). Although this slogan was not part of the Dade County campaign, it was the only theme that was common among gay activists across the country at the time. For a discussion on how ineffective the "gay-is-good" slogan was, see Andrew M. Jacobs, Romer Wasn't Built in a Day: The Subtle Transformation in Judicial Argument Over Gay Rights, 1996 WIs. L. REV, 893, 898 (1996).

180. See supra notes $106-10$, and accompanying text.

181. FEJES, supra note 124, at 139.

182. See supra notes $152-167$, and accompanying text.

183. See CLENDINEN \& NAGOURNEY, supra note 31, at 304.

184. Id. at 64 .

185. See Gregory Herek, Heterosexuals' Attitudes Toward Lesbians and Gay Men: Correlates and Gender Differences, 25 J. OF SEX RES, 451 (1988) (discussing studies that showed the varying views about gay people with a focus on the differences between genders).

186. It is important to note that Fisher differentiated between logic and rationality, as seen by his description of the rational-world paradigm. In fact, narrative rationality does not always mean logical. See, e.g., Alan Bush \& Victoria Bush, The Narrative Paradigm as a Perspective for Improving Ethical Evaluations of Advertisements, 23 J. ADVERTISING 31, 34-35 (1994). As the courts later determined, there is no evidence that gay people are more likely to harm children than others.

187. See supra notes 152-167, and accompanying text.

188. President Nelson Mandela, Speech at Launch of the Nelson Mandela Children's Fund (May 8,1995 ) in SOUTH AFRICA HISTORY ONLINE ("There can be no keener revelation of a society's soul than the way it treats its children.").

189. For a description of how families have been depicted on television through the decades, see TELEVISION AND THE AMERICAN FAMILY 137-62 (Jennings Bryant \& J. Alison Bryant eds., 2001). 
with parents and aligned with the cultural views of family. ${ }^{190}$ It essentially personalized the message to voters with children (or who may want to have children), making it consistent with their own experiences and values. ${ }^{191}$ This gave the message strong narrative fidelity. The proponents also gave this message narrative fidelity by supporting claims that gay men are more likely to be pedophiles with references to stories from reputable newspapers about men arrested for soliciting sex from young boys. ${ }^{192}$ These stories seemed to provide proof that gay men are predisposed to harm children, giving credibility to these provocative claims. ${ }^{193}$ Further, the narratives were often created by people considered to be moral leaders, ${ }^{194}$ so they seemed rational - if a minister or priest says that this will be bad for my children, who am I to question them? Finally, they framed their arguments to evoke fear, one of the best ways to motivate voters, thereby adding narrative fidelity to their claims. ${ }^{195}$

The narrative that gay people are dangerous to children also helped move the Florida legislature to pass a law banning adoptions by gays and lesbians, which occurred shortly after the Dade County vote in $1977 .{ }^{196}$ The ban was strictly enforced for several decades until the Florida Third District Court of Appeals found the statute unconstitutional under Florida law in 2010. ${ }^{197}$

Anti-gay activists used similar efforts to stop anti-discrimination laws in cities across the country, often focusing on the need to protect children. In Eugene, Oregon, a gay rights ordinance was defeated in 1977 with the campaign theme: "Keep it straight. Our children come first." 198 In Wichita, Kansas, anti-gay

190. Arland Thornton and Linda Young-DeMarco, Four Decades of Trends in Attitudes toward Family Issues in the United States: The 1960s through the 1990s, 63 JOURNAL OF MARRIAGE AND THE FAMILY 1009, 1030 (2001) (detailing the importance people place on having children).

191. Id.

192. See supra notes 156-161, and accompanying text. Fejes documents numerous examples in his book, including these headlines: "Boy Prostitution: Why is a 13-Year Old Selling His Body?"

"Teacher Accused of Sex Acts with Boy Students," "4 Men Accused of Abusing," and "Homosexuals Used Scout Troop," FEJES, supra note 124, at 137.

193. Id.

194. Many church leaders supported the "Save Our Children" campaign, including Rev, Jerry Falwell and local pastors, ministers, and priests. FEJES, supra note 124, at 94 (listing the religious leaders in support of Bryant's efforts).

195. See Michael William Pfau, Who's Afraid of Fear Appeals? Contingency, Courage, and Deliberation in Rhetorical Theory and Practice, 40 PHIL, \& RHETORIC 216 (2007) (discussing how fear motivates people, communities, and political systems).

196. Shortly after the Dade County vote, the Florida legislature passed a ban on adoption by homosexuals. FLA. STAT. ANN. \& 63.042 (1977) ("No person eligible to adopt under this statute may adopt if that person is a homosexual"). See William Adams, A Look at Lesbian and Gay Rights in Florida Today: Confronting the Lingering Effects of Legal Animus, 24 NOVA L. REV. 751, 768 (2000). See also Allan H. Terl, An Essay on the History of Lesbian and Gay Rights in Florida, 24 NovA L. REV. 793, 804-05 (2000) (associating Florida's enactment of a prohibition on gay adoption with the national attention brought to the state by Anita Bryant's political campaign); Yolanne Almanzar, Florida Gay Adoption Ban Is Ruled Unconstitutional, N.Y. TIMES, Nov, 26, 2008, at A21, available at http://www.nytimes.com/2008/11/26/us/26florida.htm1?_r=0 ("The [Florida] Legislature voted to prohibit adoptions by gay men and lesbians in 1977, in the midst of a campaign led by the entertainer Anita Bryant to repeal a gay rights ordinance adopted by Dade County.").

197. FLA. STAT, ANN, \& 63.042. See BRYANT, supra note 126, 125-31; In re Adoption of John Doe \& James Doe, No. 2008 WL 5006172 (11th Cir. 2008) (hearing in front of Judge Lederman).

198. FEJES, supra note 124, at 176-78. 
activists, including Bryant, produced a political ad that compared gays to pedophiles, with other campaign materials discussing the dangers of having gay teachers recruit students to be gay. ${ }^{199}$

Following the successes that Bryant and others were having in defeating anti-discrimination laws, gay rights opponents in California took the narrative a step further and pushed for a ban on gays and lesbians teaching in the public schools. ${ }^{200}$ This effort, known as Proposition 6, was spearheaded by a California State Senator, John Briggs. ${ }^{201}$ It was meant to bar gays, lesbians, and those who advocated or promoted homosexual activity from teaching in California schools. 202 Briggs' organization, named "California Defend Our Children," played off of the same themes presented by "Save Our Children." 203 Because California is such a large state with large media outlets, the debate became the next widely-publicized national debate on gay rights. ${ }^{204}$ Sensing a more difficult fight, Senator Briggs decided to heighten his rhetoric about the harm that gay teachers present to children, but he kept with the same themes that gays need to recruit children, are predisposed to cause physical harm, and are more likely to seduce and molest children:

Homosexuals want your children. They don't have any children of their own. If they don't recruit children or very young people, they' $\mathrm{d}$ all die away. They have no means of replenishing. That's why they want to be teachers. ${ }^{205}$

Homosexuality is a more insidious threat than Communism: It is like a creeping disease where it just continues to spread like a cancer throughout the body. 206

A homosexual school employee should be dismissed, even absent a physical or verbal threat to a student, because he's a threat to children. We already know that homosexuals are attracted to children. If you look like a duck, and you walk like a duck, in my opinion, my friend, you are a duck. If you have a proclivity for having sex with young boys or people of your own gender, then you ought not be put in a position where you are going to be tempted. ${ }^{207}$

Children in this country spend more than 1,200 hours a year in classrooms. A teacher who is a known homosexual will automatically represent that way of life to young, impressionable students at a time when they are struggling with their own critical choice of sexual orientation. When children are constantly exposed to such homosexual role models, they may well be inclined to experiment with a life-style that could lead to disaster for themselves and ultimately for society as a

199. Id. at 174-75. Fejes' book describes in detail the similar themes in the referenda that followed Dade County's vote, highlighting how the campaigns continued the protect-the-children arguments. $I d$, at 153-79.

200. CLENDINEN \& NAGOURNEY, supra note 31 , at 377-81.

201. Id.

202. Id.

203. Id.

204. Id.

205. Charles KAISER, THe Gay METROPOlis; 1940-1996, at 276 (1997) (quoting Sen, John Briggs).

206. CLENDINEN \& NAGOURNEY, supra note 31, at 388 (quoting Sen. John Briggs' comments made the day before the election).

207. Id. at 388 (quoting Sen. John Briggs' comments made during an interview with the L.A. Times) 
whole. ${ }^{208}$

A leaflet from the "California Defend Our Children" campaign showed a teenage boy lying in a pool of blood and stated:

You can act right now to help protect your family from vicious killers and defend your children from homosexual teachers. ${ }^{209}$

We can't accept you as normal because you are not normal people. The only way to get children is to recruit our children. I can't think of a better setting than the classrooms. ${ }^{210}$

All of these statements were in line with the previous media coverage and campaign themes in Dade County, giving them narrative rationality - they were consistent with what was already stated about gay people through these previous campaigns. The proposition ultimately failed, most likely because of its over-inclusive language that could have caused heterosexual teachers to face charges and be dismissed if they promoted or encouraged any act of homosexuality. 211 Even so, the strong rhetoric from the Florida, Oregon, Kansas, and California campaigns, which drew national attention, helped frame the debate about gays and children, focusing the public on a narrative that gays recruit children because they do not reproduce, they present a physical danger to children because they are sexual predators who often prey on children, and that children will be taught that being gay is morally correct. ${ }^{212}$ Regardless of its validity, the sheer repetition of the claim that gay people are more harmful to children helped provide it strong narrative rationality. ${ }^{213}$

\section{B. Events and Debates that Cemented the Narrative}

Within a few years, HIV/AIDS became a national crisis that helped strengthen the narrative that gay people can harm children. In the news throughout the 1980s and 1990s, parents and families were witnessing the perceived consequences of homosexuality - the possibility of a very painful death. ${ }^{214}$ In the early days of the disease and for many years that followed, most

\footnotetext{
208. Id. at 381 (discussing a column in the Los Angeles Times that quotes John Briggs).

209. Id.

210. Id.

211. See Eskridge, supra note 136, at 1018. The proposition was opposed by then Governor Ronald Reagan, who believed that it threatened to "embroil schools in ongoing disputes and litigation over teachers' statements" about anything related to homosexuality. CLENDINEN \& NAGOURNEY, supra note 31, at 381; JOHN GALLAGHER \& CHRIS BULL, PERFECT ENEMIES: THE RELIGIOUS RigHT, THE GAY MOVEMENT, AND THE POLITICS OF THE 1990s, at 10 (1996) (quoting Reagan as saying: "What if an overwrought youngster, disappointed by bad grades, imagined it was the teacher's fault and struck out by accusing the teacher of advocating homosexuality. Innocent lives could be ruined.").

212. For examples of the rhetoric used, see supra notes 162-70 and 207-19, and accompanying text.

213. See Kimberlee Weaver, et al., Inferring Popularity of an Opinion from its Familiarity: A Repetitive Voice Can Sound Like a Chorus, 92 J. PERSONALITY \& SOC. PSYCHOL. 821 (2007) (discussing how people tend to believe an opinion because it is repeated). See also, Jeremy N. Sheff, The Myth of the Level Playing Field: Knowledge, Affect, and Repetition in Public Debate, 75 MO. L. REv. 143 (2010),

214. For an example of the images that people associated with AIDS in the early years, see LIFE Behind the Picture: The Photo That Changed the Face of AIDS, LIFE, http://life.time.com/history/the-
} 
people equated HIV/AIDS with homosexuality and drug use, both of which most Americans considered morally wrong. ${ }^{215}$ The salient and difficult pictures of men dying played into the narrative that being gay was harmful in itself, causing parents to take action to protect their children and prevent them from being gay and ultimately dying. ${ }^{216}$

In addition to the HIV/AIDS crisis, the narrative that gay people harm children was later strengthened by a series of high-profile events and gay rights debates. Most notable among the events that helped cement the harm-to-children narrative were the rise of the Moral Majority and the establishment of their "experts," the rise in ballot measures to limit gay rights, and the visible Catholic Church molestation scandals. Around the same time as the Catholic Church scandals, a highly charged debate arose concerning the Boy Scouts' ban on gay members and leaders.

\section{Rise of the Moral Majority}

After the HIV/AIDS crisis brought more gay activists out into the public, local groups began having success advancing anti-discrimination laws. ${ }^{217}$ Meanwhile, many of the same people who helped Anita Bryant and John Briggs in their anti-gay campaigns later formed religious organizations to capitalize on their political successes. These groups continued fighting gay rights laws, and also began using their political experience to limit abortion rights and fight for various other Christian beliefs. ${ }^{218}$ For example, Jerry Falwell, who played a large role in the Florida and California campaigns, started the Moral Majority in 1979.219 Louis Sheldon, who helped campaign for Proposition 6, later started the Traditional Values Coalition. ${ }^{220}$ These were just two of the organizations that developed over the subsequent decades to fight against gay rights and other social issues.221 Most of these organizations, including the American Family

story-behind-the-photo-that-changed-the-face-of-aids/\#ixzz2Z8eLzIpG (last visited Oct. 4, 2013).

215. See, e.g., Vickie Mays \& Susan Cochran, Issues in the Perception of AIDS Risk and Risk Reduction Actizities by Black and Hispanic/Latina Women, 43 AM. PSYCHOLOGIST, 949, 949 (1988) ("Until recently, most Americans thought of Acquired Immunodeficiency Syndrome (AIDS) as essentially a man's disease afflicting homosexual, bisexual, and intravenous drug abusing males. ...").

216. This narrative is based on the underlying idea that gay people can change their sexual orientation and that they need to recruit children. Neither of these ideas is based on any real evidence; the narrative rationality doesn't require that the arguments be based in logic. Rather, people judge narrative rationality mostly on their values and whether the idea "rings true." See Bush \& Bush, supra note 186, at 34-35 ("Such reasons are not always bound to logical argument or empirical support-they can also be based on the moral of the story...."). See also MICHAEL GOLDBERG, THEOLOGY AND NARRATIVE 242 (1982) (explaining how our moral principles guide our evaluation of facts and experiences).

217. See supra note $30-37$, and the accompanying text.

218. For a discussion on the rise of the Moral Majority, see Doug Banwart, Jerry Falwell, the Rise of the Moral Majority, and the 1980 Election, 5 W. ILL. HIST. REV. 133 (2013).

219. Id.

220. See THE TRADITIONAL VALUES COALITION, http://www.traditionalvalues.org/content/about (last visited Oct. 4, 2013).

221. Charlene Smith, Undo Two: An Essay Regarding Colorado's Anti-Lesbian and Gay Amendment 2, 32 WASHBURN L.J. 367, $367 \mathrm{n} .3$ (1992-1993) (citing the numerous groups that fought against gay rights). 
Association, ${ }^{222}$ Concerned Women for America, ${ }^{223}$ and the Family Research Council, continued to use the meme that gay people are harmful to children.224

These members of the religious right began taking part in every political and legal debate involving gays and lesbians, including debates over antidiscrimination laws passed at the municipal and state levels, the ban on gays and lesbians in the military, ${ }^{225}$ and the Boy Scouts' ban on gay members. ${ }^{226}$ During these political battles between the religious right and gay rights groups, those opposed to gay rights continued to use the narrative that gays are sexual predators that harm children because it worked and had narrative rationality. ${ }^{227}$

222. Started in 1977 as the National Federation for Decency and changing its name to the American Family Association in 1988. See Evelyn Schlatter, 18 Anti-Gay Groups and Their Propaganda, 140 S. POVERTY L. CTR. INTELLIGENCE ReP., Winter 2010, available at http://www.splcenter.org/getinformed/intelligence-report/browse-all-issues/2010/winter/the-hard-liners.

For an example of the type of harm-the-children rhetoric of the American Family Association, see Bryan Fischer, Why same-sex marriage is bad for children, RENEW AMFRICA (July 7, 2008), http://www.renewamerica.com/columns/fischer/080707 ("[S]ame-sex marriage will only increase sexual confusion in children and encourage dangerous sexual experimentation among the nation's youth").

223. To get a sense of this group's heightened fear of homosexuality and its impact on children see Vanessa Warner \& Trudy Hutch, Kids and Sex: The Kinsey Connection, CONCERNED WOMEN FOR AMERICA (June 1997), http://www.cwfa.org/content.asp?id=855 (discussing Alfred Kinsey, the famous psychologist who wrote the groundbreaking book on sexuality, SEXUAL BEHAVIOR IN THE HUMAN MALE (1948):

How did Kinsey come to the conclusion that children are sexual? That is the most frightening aspect of his story. Kinsey was a silent partner in the molestation of 317 children. In chapter five of his 1948 report on the human male, Tables 30-34 present data on children's orgasms - beginning with five-month-old infants.)

224. See Robert H. Knight \& Frank V. York, Homosexual Behazior \& Pedophilia, FAM. ReS. CounCIL (1999), available at http://www.splcenter,org/get-informed/intelligence-files/groups/familyresearch-council (last visited Oct. 4, 2013) ("One of the primary goals of the homosexual rights movement is to abolish all age of consent laws and to eventually recognize pedophiles as the 'prophets' of a new sexual order.").

225. Although the debate about gays in the military did not involve arguments about children, it helped develop the narrative by the underlying tone that gays are sexual predators. By arguing that it would hurt morale for straight and gay troops to sleep and shower together, the anti-gay rights movement had to rely on the underlying assumption that gays are sexual predators. The fact that it was assumed that gays would either stare at or try to make sexual advances on their fellow soldiers illustrates how the public assumed that gays were sexual predators. See CRAIG A. RIMMERMAN, GAY Rights, Military Wrongs: POlitical Perspectives ON Lesbians and GaYs IN THE MiLitary 114-15 (1996).

226. See infra notes 279-285, and accompanying text.

227. See, e.g., Carol Innerst, Bennett, Teacher Share Quest for Moral Education at Hearing, WASH. TIMES, Dec. 6, 1995, at A8 (describing how Rev. Lou Sheldon, of the Traditional Values Coalition, has complained "about federal dollars being misused to promote homosexual lifestyles to impressionable children in America's public schools"); Peter Bacque, Debate On Homosexuals: Clash Of Cultures, RICHMOND TIMES-DISPATCH, April 6, 1993, at B1 (detailing some of the arguments made by gay rights opponents that focused on children:

Of all the problems in America today, the homosexual movement poses the most serious threat to families and to our children.

- Beverly LaHaye, head of Concerned Women for America in Washington.

'Our real problem with the agenda is (that) they go after our children, they go after our tax dollars, they try to force their moral beliefs upon us through sensitivity training, you have to hire them,' said Martin Mawyer of the Christian Action Network, 'and finally they try to legitimize their behavior.' 
In Fisher's paradigm, he describes the role that experts play in providing rationality to narratives.228 Often, experts, including ministers, judges and lawyers, politicians, and social scientists, will insert themselves into public moral arguments. ${ }^{229}$ These are the people Fisher believes are the most qualified to argue under the rational-world paradigm. ${ }^{230}$ However, when faced with public moral debates, the public generally has no reason to believe one expert over another because people interject their own values and experiences when evaluating the narrative for coherence and fidelity instead of listening to logic and reason. ${ }^{231}$ Therefore, the most effective experts in a public moral debate will be those who tie their expertise to the values and experiences of those listening to and evaluating the arguments..$^{232}$

The religious right understood this role of experts in public moral debates, so some of them promoted the work of Paul Cameron, a former psychology instructor at the University of Nebraska, as a scientific expert to support the narrative that gay people harm children. ${ }^{233} \mathrm{He}$ started an organization to help provide "scientific research" to the claims made by the religious right. ${ }^{234}$ The organization, the Institute for the Scientific Investigation of Sexuality, later became known as the Family Research Institute. 235

At the beginning of the HIV/AIDS crisis in the 1980s, Cameron claimed to be an expert in the study of homosexuality and its harms in society. ${ }^{236} \mathrm{He}$ began by producing a series of pamphlets about the problems associated with homosexuality, while the contemporaneous visual depictions of gay men with HIV/AIDS gave his stories narrative fidelity. ${ }^{237}$ Many of these pamphlets were based on some of his studies, which have been universally discredited. ${ }^{238}$ These

\footnotetext{
'They're trying to ... make their actions considered normal in our society, and they're not normal,' said Keri Harrison with Concerned Women for America. 'In fact, they're dangerous. .. . They engage in life-threatening behavior. That's clear because of AIDS.'

'It's not a question of liking or disliking homosexuals,' Shirley said. 'I myself take what is considered a libertarian attitude: What somebody does in their own house is their own damn business ... and I think most people would agree with that, as long as no drug laws are violated and it's not with children.' However, he said, 'There's a huge difference between what people do in their own homes and what's taught in public schools.'

'These individuals say it's OK to have sex with consenting boys... . I'm not saying every child molester is a homosexual, but most child molesters are homosexuals,' [Martin Mawyer of the Christian Action Network] said.

'[P]edophilia is a psychological illness,' Ms. Kane said, 'that has nothing whatever to do with gay and lesbian civil rights.')

228. FISHER HUMAN COMMUNICATION, supra note 16 , at 73-75.

229. Id. at 72 .

230. Id.

231. Id.

232. Id. at 73 ("When the full range of good reasons for responses is taken into consideration, experts and laypersons meet on the common ground of their shared, human interests.").

233. See GALLAGHER \& BuLL, supra note 211.

234. Id.

235. Id. See also FAM. RES. INST,, http:/ / www,familyresearchinst.org (last visited Oct. 4, 2013).

236. See GALLAGHER \& BULL, supra note 211.

237. Id.

238. See Michael Kranish, Beliefs Drive Research Agenda of New Think Tanks, THE BOSTON GLOBE, July 31, 2005, available at 2005 WLNR 12055356.
} 
pamphlets continued to push some of the same lines that were advocated by the anti-gay rights movement from the Bryant era by claiming that gays are more violent and that they molest,_rape, and murder children at a higher rate than the general population does. ${ }^{239}$ For example, in one pamphlet, entitled Violence and Homosexuality, which studied serial killers, Cameron claimed that gay people are disproportionately more violent than heterosexuals. ${ }^{240} \mathrm{He}$ is most notable, however, for his numerous pamphlets and studies that charge that gays are more likely than the general population to be child molesters. ${ }^{241}$ In these studies and pamphlets, he makes several assertions that gays are responsible for more than one third of all child molestations and that gays are ten to twenty times more likely than heterosexuals to molest children. ${ }^{242}$ Many of Cameron's statements have later been used by the anti-gay rights movement to support its claims that gays harm children, even though such claims have been widely discredited. ${ }^{243}$

With these and several other papers and books, Cameron gave gay rights opponents support for their continued narrative that gays are both physically violent and are more likely to molest children. ${ }^{244}$ He successfully did this by inserting values regarding sexuality, family, and religion into his arguments,

239. See Paul Cameron, Violence and Homosexuality, FAM. RES. INST. BLOG, http://www.familyresearchinst.org/2009/02/violence-and-homosexuality/ (last visited Oct. 4, 2013).

240. Id.

241. See, e.g., Paul Cameron, Homosexual Molestation of Children/Sexual Interaction of Teacher and Pupil, 57 PSYCHOL. REP. 227 (1985); Paul Cameron, Child Molestation and Homosexuality, FAM. RES. INST. BLOG, http://www.familyresearchinst,org/2009/02/child-molestation-and-homosexuality-2/ (last visited Octt. 4, 2013).

242. Cameron, Homosexual Molestation of Children/Sexual Interaction of Teacher and Pupil, supra note 241; Cameron, Child Molestation and Homosexuality, supra note 241.

243. Paul Cameron, Medical Consequences of What Homosexuals Do, FAM. RES. INST. BLOG, http:/ / www.familyresearchinst.org/2009/02/medical-consequences-of-what-homosexuals-do/ (last visited Oct. 4, 2013) (describing a study where he looked at the obituaries from several gay newspapers). Some of his statements about the harm to children include:

"If $2 \%$ of the population is responsible for $20 \%$ to $40 \%$ of something as socially and personally troubling as child molestation, something must be desperately wrong with that $2 \%$. Not every homosexual is a child molester. But enough gays do molest children so that the risk of a homosexual molesting a child is 10 to 20 times greater than that of a heterosexual." Cameron, Child Molestation and Homosexuality, supra note 241.

"Not only is the gay rights movement upfront in its desire to legitimize sex with children, but whether indexed by population reports of molestation, pedophile convictions, or teacher-pupil assaults, there is a strong, disproportionate association between child molestation and homosexuality." $I d$.

"That this group [gays] also accounts for around a third of child molesters, commits between a third to two-thirds of child rapes, and may be involved in up to half of all murders, adds substance to the traditional belief that participation in homosexual activity is anti-social." Paul Cameron, Homosexual Rape and Murder of Children, J. FAM. RES. INST. (April 14, 2003, 8:06 PM), http:// www.freerepublic.com/focus/fr/893184/posts.

A 1993 study [demonstrated] that the average life span of a gay man who died of AIDS was 39, and that of one who died from other causes was 42. Cameron, Medical Consequences of What Homosexuals Do, supra note 243.

Even some judges have cited to Cameron for his research. See, e.g., Goodridge v. Dept. of Pub. Health, 798 N.E.2d 941, 999, n. 26 (Mass. 2003) (dissenting opinion citing Paul Cameron, Homosexual Parents, 31 ADOLESCENCE 757, 770-74 (1996) to claim "that children raised by homosexuals disproportionately experience emotional disturbance and sexual victimization.").

244. See supra notes $239-43$, and accompanying text. 
helping to establish narrative fidelity with those listening to the messages from gay rights opponents. ${ }^{245}$

Although widely discredited and formally disassociated from the American Psychological Association, ${ }^{246}$ the Nebraska Psychology Association, ${ }^{247}$ and the American Sociological Association, 248 Cameron's work has been cited by gay rights opponents throughout the past twenty-five years. ${ }^{249}$ With Cameron giving gay rights opponents the "scientific" backing to make the claims, the anti-gay rights movement was able to further cement the narrative that gays are more likely than heterosexuals to recruit, seduce, and molest children. ${ }^{250}$ Although most people do not know about Cameron, his work has been very influential within the religious right community. For example, Gale Norton, attorney general of Colorado in 1992, hired Cameron to act as an expert witness in Romer v. Evans, the case that challenged the anti-gay Amendment Two in Colorado. ${ }^{251}$ Cameron also acted as an expert witness in a challenge to Texas's sodomy laws in 1984, where the federal judge admonished him for making misrepresentations to the court. ${ }^{252}$ He was even cited in a law review article arguing that there is an immediate need to fight against gay rights because gays are more likely to molest children. ${ }^{253}$

245. The Family Research Council's mission ties morality to the research it does:

Family Research Institute is a non-profit scientific and educational corporation that believes the strength of our society depends on preserving America's historic moral framework and the traditional family. FRI is working to produce sound, scientific data on pressing social issues - especially homosexuality - in an effort to promote traditional policies. We welcome all who would join in the fight to restore a world where marriage is upheld and honored, where children are nurtured and protected, and where homosexuality is not taught and accepted, but instead is discouraged and rejected at every level.

FAM. REs. COUNCIL, http://www.familyresearchinst.org/ (last visited Oct. 4, 2013).

246. See Kranish, supra note 238 (discussing how he was dropped from the membership).

247. Id. (quoting the association as saying that it "formally dissociates itself from the representations and interpretations ... offered by Dr. Paul Cameron.").

248. Id. (discussing how the Association passed a resolution stating that "Cameron has consistently misinterpreted and misrepresented sociological research on sexuality, homosexuality, and lesbianism.").

249. Id. For examples of how his work is still being used, see, e.g., Franklin Payne, Letter to the Editor, ASU Suit Highlights Confusion over Truth, AUGUSTA CHRONICLE, Aug. 19, 2010, at A6, available at http://chronicle.augusta.com/opinion/letters/2010-08-19/asu-suit-highlights-confusion-overtruth; Nicky Phillips \& Barney Zwartz, 'Unhealthy' Gay Lifestyle Claims Tied to Bad Study, SYDNEY MORNING HERALD, Sept. 12, 2012, at 4, available at http://www.smh.com.au/federalpolitics/political-news/unhealthy-gay-lifestyle-claims-tied-to-bad-study-20120911-25qnd.html; April Washington, Amia Debate on Gays, Senate Panel Approves Adoption Bill, RoCKY MTN. News, Apr. 3, 2007, at 21, available at http://www.rockymountainnews.com/news/2007/apr/03/amid-debate-ongays-senate-panel-approves-bill/.

250. See Cameron, supra note 243.

251. See Sean Cahill, The New Battle Lines are Drawn, 8 GAY \& LeSBIAN REV. 25 (June 30, 2001).

252. Baker v. Wade, 106 F.R.D. 526, 537-38 (N.D. Tex. 1985) (discussing Paul Cameron, who the court found "made misrepresentations to this Court.").

253. See Steve Baldwin, Child Molestation and the Homosexual Movement, 14 REGENT U. L. REV. 267, 278 (2001-02) (discussing Cameron's work affirmatively by stating that his work found "that homosexuals account for between $25 \%$ and $40 \%$ of all child molestation."). 


\section{The Anti-Gay Initiatives}

The HIV/AIDS crisis made more gays and lesbians visible to the public. Fearing that the federal government was not doing enough to stop the spread of a disease that was killing thousands of gay men, gay rights activists became much stronger and more visible. ${ }^{254}$ Gay rights groups became better organized and began to fight for more legal protections, which only heightened the efforts of gay rights opponents who continued to use the narrative that gay people are harmful to children in supporting initiatives that would repeal or limit gaypositive laws. 255

In several states during the early 1990s, ballot initiatives appeared that prevented municipalities from passing anti-discrimination laws based on sexual orientation, ${ }^{256}$ prohibited state or local money from encouraging homosexuality, ${ }^{257}$ and prevented hate crime protections for gays and lesbians..$^{258}$

Although most arguments for these initiatives focused on not wanting to provide "special rights" to gays and lesbians, gay rights opponents continued to use the narrative that gays were potentially harmful to children, claiming that gays recruit, seduce, and molest children and using Paul Cameron's studies as support. Some examples of arguments made during these initiatives include:

An initiative that ultimately lost in Oregon would have defined homosexuality as "abnormal, wrong, unnatural, and perverse." This initiative and one proposed in Arizona would have equated homosexuality with pedophilia. The organization that pushed the Oregon initiative and others produced a video entitled "No Special Rights," which included gay pride parade footage with interviews that focused on "sadomasochism and pedophilia." 259

A key proponent of an initiative that would bar anti-discrimination laws based on sexual orientation stated, "Many, many homosexuals are recruited at a very young age, low teens, very, very typical." 260

254. See GALLAGHER \& BULL, supra note 211 (discussing how the emergence of AIDS helped propel the gay community to become more politically active). See also Douglas Crimp, Right On, Girlfriend!, 33 SOCIAL TEXT, 1992, at 2 (detailing the efforts of gay rights activists to humanize the disease).

255. See infra notes 262 to 269 , and accompanying text.

256. The most famous of these initiatives came out of Colorado as Amendment Two. This amendment barred any municipality from passing any laws that outlawed discrimination based on sexual orientation. This amendment became the focus of Romer $v$. Evans, a Supreme Court opinion invalidating the law under the equal protection clause of the United States Constitution. Other state or local initiatives that banned anti-discrimination protections based on sexual orientation included Oregon, Cincinnati, Idaho and Maine. See generally, ANTI-GAY RIGHTS: ASSESSING VOTER INITIATIVES 165 (Stephanie Witt \& Suzanne McCorkle eds., 1997).

257. A measure in Oregon, which ultimately failed, prohibited all governmental entities from spending money to "promote, encourage, or facilitate homosexuality, pedophilia, sadism, or masochism." See ANTI-GAY RIGHTS, supra note 256, at 165.

258. See Ralph Smith, Secular Anti-Gay Advocacy in the Springfield, Missouri, Bias Crime Ordinance Debate in ANTI-GAY RIGHTS, supra note 256, at 95-106.

259. David Douglas, Taking the Initiative: Anti-Homosexual Propaganda of the Oregon Citizen's Alliance, in ANTI-GAY RIGHTS supra note 256, at 21-24.

260. Harvey Pitman, In Their Own Words: Conversations with Campaign Leaders, in ANTI-GAY RIGHTS, supra note 256 , at 78 (stating that part of the reason to pass the initiative was to prevent the normalization of homosexuality and the recruitment of children). 
In a debate about a proposed Springfield, Missouri bias crime ordinance, several arguments were made that gays were a threat to children, saying that the ordinance would protect child molesters. ${ }^{261}$

Several arguments made during Colorado's Amendment Two debate, which produced Romer $v$. Evans, claimed that gays recruit children to the "homosexual lifestyle," which produces AIDS and sickness. ${ }^{262}$

Colorado for Family Values, the organization that pushed Amendment Two, made claims that gays molest children. ${ }^{263}$ The state paid Paul Cameron $\$ 15,000$ as a consultant on the legal case. ${ }^{264}$

Not only was the harm-to-children argument made during the anti-gay rights-initiative debates, it was commonly made before by gay rights opponents during the 1980s and 90s about anything related to gays and lesbians. For instance, in debates about whether gays should adopt or foster children, the danger posed by gay parents was often mentioned and even highlighted. ${ }^{265}$ In addition, the rise of presidential candidates Patrick Buchanan and Pat Robertson heightened the "culture wars" during the 1990s, with both often making claims that gay people will recruit children and are more likely to molest them. ${ }^{266}$ Gay rights opponents also tried to make arguments about the harm to children when debating the military's ban on gays and lesbians. ${ }^{267}$ Even though most of the gay rights debates during the 1980 s and 1990s did not directly involve children or family, gay rights opponents continued to advance this well-tried narrative for emotional impact. ${ }^{268}$ Unfortunately for gay rights activists, this specious

261. Ralph Smith, Secular Anti-gay Advocacy in the Springfield, Missouri, Bias Crime Ordinance Debate, in ANTI-GAY RIGHTS, supra note 256, at 101-02.

262. Sharon E. Debbage Alexander, Romer v, Evans and the Amendment 2 Controversy: The Rhetoric and Reality of Sexual Orientation Discrimination in America, 6 TEX. F. ON C.L. \& C.R. 261, 272-73 (2002) (citing reports made on the Bill Moyers' Journal shown on PBS entitled "The New Holy War").

263. Study: Most Molesters not Gay, ROCKY MTN. NEws, Sept. 29, 1992, at 31 ("Campaign literature distributed by [Colorado for Family Values] states that gays commit up to half of all child molestations"). A list of the statements made by Colorado for Family Values that depict gays as a danger to children appears at http://www.hatecrime.org/subpages/hatespeech/narth.html.

264. See Kranish, supra note 238.

265. See WE ARE FAMILY (Filmmakers Library, Inc. 1987) (Showing statements about the danger to children similar to those made by New Hampshire legislators who claimed that the "only way they can sustain their lifestyle is to proselytize and I don't want any child subjected into that").

266. See Pat Robertson Quotations, POSITIVE ATHEISM, http://www.positiveatheism.org/hist/quotes/revpat.htm (last visited Oct. 4, 2013) (listing fear comments that Pat Robertson makes on his 700 Club television show); see generally PAT ROBERTSON, BRING IT ON (2003) (containing more fear comments of Pat Robertson). Patrick Buchanan made several comments about gays and lesbians during his campaign for president, his speech at the Republican convention on August 17, 1992, and in subsequent appearances about his speech. To see excerpts of his speeches, see THE QUESTION OF EQUALITY: CULTURE WARS (Koed Video 1995).

267. In a fundraising letter for the Coral Ridge Ministries, the pastor asked if you would "want your son, daughter, or grandchild sharing a shower, foxhole, or blood with a homosexual?" See The Thirty Years War, 117 S. POVERTY L. CTR. INTELLIGENCE REP. (2005), available at http:/ / www.splcenter.org/get-informed/intelligence-report/browse-all-issues/2005/spring/thethirty-years-war?page $=0,1$ (last visited Oct. 4, 2013).

268. See Jane S. Schacter, The Gay Cizil Rights Debate in the States: Decoding the Discourse of Equizalents, 29 HARV. C.R.-C.L. L. REV. 283, 289 (1994) (discussing how opponents of gay rights moved from a focus on children to an argument that anti-discrimination laws provide "special 
argument had strong narrative rationality with voters and politicians. ${ }^{269}$

\section{Catholic Church Molestation Scandals}

To further support the idea that gay men harm children, gay rights opponents used a very visible and highly-publicized scandal that emerged out of the Catholic Church. The scandal focused on priests molesting boys and the church covering up the abuse. ${ }^{270}$ The media coverage of the Catholic Church molestation scandals provided a visual depiction of the narrative that gay men are harmful to children by showing the images of boys with Catholic priests. ${ }^{271}$ The coverage also allowed the boys (who often had already grown up) to tell their stories of abuse, which gave credibility to the narrative and supported the "good reasons" that many already had for fearing gay men - that they are more likely to harm children than others, even when in such highly regarded positions as priests.

The media coverage also tended to equate homosexuality with pedophilia, either implicitly or explicitly, as shown by a study of the coverage in Boston, the scandal's epicenter. ${ }^{272}$ The study identified the ways the media linked homosexuality to the church's child abuse scandal. ${ }^{273}$ First, the media made "direct conflations of homosexuality and child sexual abuse that were offered either as original statements or as representations of a third party source." 274 There also were news stories that concerned gay priests and were "juxtaposed with reports of sexual crimes, without an explanation or explicit connection." 275 Citing to numerous examples from the Boston Globe, the report found that the newspaper exposed readers "to an average of two articles per week during 2002 that linked abuse and homosexuality." 276

With the direct and indirect conflation of homosexuality and the church abuse scandal, opponents of gay rights used the media attention to provide fidelity to the narrative that gay people are harmful to children. For example, in an effort to deflect the argument that the scandal was caused and perpetuated by

rights").

269. Id. (highlighting how gay rights opponents still found arguments using children to have narrative rationality because these arguments were still used even when the law had no direct impact on children).

270. The John Jay College of Criminal Justice, The NATURE and SCOPE OF the Problem of SeXual Abuse of Minors by Catholic PRIESTS AND DeACONS IN THE UNITEd STATES, 1950-2002, (2004), available at http://www.bishop-accountability,org/reports/2004_02_27_JohnJay_revised/ 2004_02_27_John_Jay_Main_Report_Optimized.pdf.

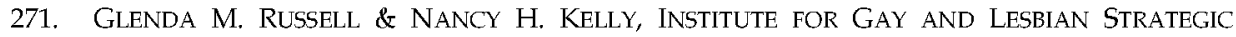
Studies, Subtle Stereotyping: THe Media, HomOSeXuality, and the Priest SeXual Abuse SCANDAL (2003), available at http://www.theinterface.org/media/pdf/MediaStereotype.pdf.

272. Id.

273. $I d$.

274. Id. at 1, 9-12 (detailing examples of when the Boston Globe allowed the direct conflation of homosexuality and the church crisis, including the following quote: "The Vatican, in its first comments on the clergy sexual abuse crisis, declared this weekend that gay men should not be ordained as priests.").

275. Id. at 1, 12-18 (providing examples of the ways the articles indirectly linked homosexuality to the church abuse scandal, including using phrases like "man-boy sex").

276. Id. at 1 . 
the Catholic Church, anti-gay activists within the church often blamed it on homosexuality:

[T]he true nature of the problem in the Catholic Church is not pedophilia, but homosexuality, which can lead to sexual relations with sexually mature but underage boys.

Neither the media nor the Church have made it clear to the public that most of the abuse cases involve teenage boys, for this would focus the issue on the problems of homosexuality, a topic that is not politically correct. By not making this clear, the media has given the impression that the Catholic Church attracts sick priests who like little children, as opposed to homosexuals who like teenage boys[.] $]^{277}$

Although not evidence that gay men were more likely to molest children, the scandal provided gay rights opponents the "proof" they needed to advance their narrative at a time when it was being challenged by the greater visibility of gay people in society..$^{278}$

\section{The Boy Scouts Debate}

Around much of the same time as the Catholic Church molestation scandal was covered by the media, another public debate emerged surrounding the Boy Scouts of America's policy of not allowing gay members or scoutmasters. ${ }^{279}$ This debate illuminated how widely held the narrative that gay men are harmful to children was in society. ${ }^{280}$ The Boy Scout debate occurred in such close proximity to the Catholic Church scandal that it was easy for the public to see the danger of

277. Leon J. Podles, Catholic Scandals: A Crisis for Celibacy? TOUCHSTONE, April 2002, available at http://www.touchstonemag.com/archives/article.php?id=15-03-025-f. Other officials and defenders of the church made similar comments. See, e.g., Matt C. Abbott, Homosexuality and the Church Crisis, RENEW AMERICA (Apr, 24, 2010), http://www.renewamerica.com/columns/abbott/100424 ("In fact, a number of studies performed over a period spanning more than half a century - many of which were performed by homosexuals or their sympathizers - have shown that an extremely large percentage of sexually active homosexuals also participate in child sexual molestation ... This is not 'homophobia' or 'hatred.' This is mere scientific fact.") (quoting essay by Brian W. Clowes); Bill Donohue, Catholic Church's Issue is Homosexuality, Not Pedophilia, THE WASH. POST, July 22, 2010, available at http:// newsweek.washingtonpost.com/onfaith/guestvoices/2010/07/Catholic_churchs_issue_is_ho mosexuality_not_pedophilia.html ("The conventional wisdom maintains there is a pedophilia crisis in the Catholic Church; I maintain it has been a homosexual crisis all along. The evidence is all on my side, though there is a reluctance to let the data drive the conclusion. But that is a function of politics, not scholarship.").

278. Paul R. Brewer, The Shifting Foundations of Public Opinion about Gay Rights, 65 J. OF POL. 1208 (2003) (discussing the large movement of popular opinion about gay rights during the 1990s).

279. The debate about whether to allow gay people into the Boy Scouts is described in detail in Boy Scouts of America v. Dale, 530 U.S. 640 (2000).

280. Although the Boy Scouts' organization position on the ban was based on the claim that homosexuality violated the oath taken by scouts to be morally clean, the anti-gay rights movement was very open about the reason that it supported the ban: "For the very same reasons that the Boy Scouts said they didn't want to have homosexual scoutmasters-because homosexuals by definition are people who are attracted to people of the same sex - this should never have been allowed within the Roman Catholic priesthood." Dwayne Hastings, Catholic Sex Scandal Eroding Faith in Religious Institutions, Land Says, Baptist Press, July 30, 2002, azailable at http:/ / www.bpnews.net/bpnews.asp?ID=13927. 
leaving children with gay men. In fact, many people explicitly made the connection between the Catholic Church scandal and the Boy Scouts. ${ }^{281}$ Even during the recent debate about the Boy Scouts changing their policy to allow gay boys to be scouts, gay rights opponents voiced concern that allowing homosexuals to participate in the Boy Scouts would put children in danger, even though the evidence does not support this view. ${ }^{282}$ A familiar opponent to the progress of gay civil rights, the Family Research Council, led by Tony Perkins, has gone on record saying, "If the [BSA] board capitulates to the bullying of homosexual activists, the Boy Scouts' legacy of producing great leaders will become yet another casualty of moral compromise." 283 The Family Research Council publicly insinuated that admitting homosexuals into the Boy Scouts' ranks would jeopardize child safety. ${ }^{284}$ Other conservative, right-wing groups have made the same argument. 285

281. See, e.g., Jeffery Hart, The Boy Scouts Were Right After All, ALBANY HeRaLD, June 20, 2002, at A8 (warning the Boy Scouts to not accept gay leaders because of the Catholic Church Scandal).

282. See Aaron McQuade, Dozens of Experts Dispel Anti-Gay Activists' Myth About Gay BSA Leaders, GLAAD (Feb. 6, 2013, 9:30AM) http://www.glaad.org/blog/dozens-experts-dispel-anti-gayactivists-myth-about-gay-bsa-leaders ("[M]ore than 120 experts from the fields of sex abuse prevention, psychology, social work, psychiatry, child advocacy, faith outreach, criminology, education and coaching have co-signed an open letter to concerned parents and educators ... [that] directly addresses and dispels the myths being put forward in the media by anti-gay activists, who are seeking to scare parents and educators by telling them that children and minors will be less safe with gay men than they would be with straight men."). Even after the recent adoption of a new policy that allows gay scouts, the groups still doesn't allow gay scoutmasters. Implicit in this exclusion is the potential danger that gay scoutmasters pose to children. For example, Tony Perkins of the conservative Family Research Council recently connected homosexuality and pedophilia:

And first, the Boy Scouts have had a long history of struggling with an issue of protecting the boys. Last fall they were forced by the court to release about 15,000 pages that identified 1,900 predators within the Boy Scouts. And so in part their policy has been to protect boys to obviously create obviously not a perfect environment but one that is in line with what the parents want to ensure that their children are safe when they go out and go in the scouting activity.

Starting Point with Soledad O'Brien (CNN television broadcast, Feb. 6, 2013), transcript available at http:/ / edition.cnn.com/TRANSCRIPTS/1302/06/sp.01.html.

283. Kirk Johnson, In a Quick Shift, Scouts Rethink a Ban on Gays, N.Y. TIMES, Jan. 28, 2013, at A1, available at http://www.nytimes.com/2013/01/29/us/boy-scouts-consider-lifting-ban-on-gayleaders.html.

284. See FRC Abandons Ship with UPS, FAM. RES. COUNCIL (Dec. 11, 2012), http://www.frc.org/get.cfm?i=WU12L07 ("As for their longstanding policy on homosexuality, the Boy Scouts are doing what every parent would want them to: putting children's safety first.").

285. See, e.g., Bryan Fischer, Bryan Fischer: Jerry Sandusky as the New Poster Boy for Scouting, RIGHTLY CONCERNED (Jan. 28, 2013, 5:26 PM), http://www.afa.net/Blogs/BlogPost.aspx?id $=2147531729$ (claiming BSA's acceptance of gay members "represents a capitulation to the forces of sexual deviancy. The Scouts will have made a deliberate decision to put the sexual integrity of every young man in their care at risk.... Abolishing the sexual orientation standard will turn every Boy Scout in America into vulnerable prey for the sexually deviant."), Kyle Mantyla, Barber \& Stazer: 'It Makes No Sense to Have Jerry Sandusky as Your Scout Master', RIGHT WING WATcH (Feb. 5, 2013, 1:06 PM), http:/ / www.rightwingwatch.org/content/barber-staver-it-makes-no-sense-have-jerrysandusky-your-scout-master (claiming that gay activists are demanding access to children and that all gay men define themselves by the fact that they "sexually crave sex with other males[.]"); Brian Tashman, Cliff Kincaid Wants CPAC to Investigate Why Gays 'Seem Prone to Violence, Terror and Treason', RIGHT WING WATCH (March 7, 2013, 3:25 PM), http://www rightwingwatch.org/content/cliffkincaid-wants-cpac-investigate-why-gays-seem-prone-violence-terror-and-treason (characterizing 
With the very visible Catholic Church scandal where many people conflated homosexuality with pedophilia and the contemporaneous debate about the Boy Scouts' ban on gay scouts and scoutmasters, the narrative that gay people are harmful to children became cemented in the minds of many people and provided coherence and fidelity to this broad narrative. For gay rights activists, this narrative was very difficult to break, as evidenced by the many state initiatives banning same-sex marriage that passed.

\section{BREAKING THE NARRATIVE - INITIATIVES VERSUS THE JUDICIARY}

During the fight for and against marriage rights for same-sex couples, the political and judicial processes have treated and characterized same-sex couples in dramatically different ways. Among the many arguments put forth by the opponents of marriage equality during political debates, the most consistent has been on the potential harm that same-sex marriage would cause to children.286 Even in recent years, when people have been exposed to and have more knowledge about same-sex parenting, the focus on the harm to children has continued to be a major part of the campaign against marriage equality. ${ }^{287}$ These arguments focus on how children need a mother and father, how schools will be forced to teach children that homosexuality and same-sex marriage are morally equivalent to heterosexual marriage, and how children fare better with married opposite-sex parents than with gay or same-sex parents. ${ }^{288}$

Meanwhile, when gay rights supporters have gone to court seeking marriage rights or asking that bans on same-sex marriage be found unconstitutional, the courts have thoroughly vetted claims about homosexuals harming children. ${ }^{289}$ Most courts, including the U.S. Supreme Court, have sided with those seeking marriage equality in recent decisions. ${ }^{290}$ Although most courts

homosexuality as a "monster [that] wants to impose itself on our children in the schools and even the Boy Scouts of America" that will eventually lead "communism and the downfall of civilization[.]"); Brian Tashman, Rep. Palazzo Urges the Boy Scouts to Maintain Ban on Gay Members, RIGHT WING WATCH (Feb. 11, 2013, 12:30 PM), http:/ /www.rightwingwatch.org/content/rep-palazzo-urges-boyscouts-maintain-ban-gay-members (claiming that lifting the ban on gays in the BSA will have a negative effect on children); Brian Tashman, We're Not Saying Gays Are Pedophiles, But ... , RIGHT WING WATCH (Feb. 11, 2013, 3:20 PM), http://wWw.rightwingwatch.org/content/were-not-sayinggays-are-pedophiles (claiming homosexuality is connected to pedophilia and that lifting the ban on gays in the BSA will lead to an increase in child abuse).

286. See, e.g., Helen Colwell Adams, A Move Against Same-Sex Marriage, InTELligENCER J. (Oct. 22, 2005, 9:38 PM), http://lancasteronline.com/article/local/18009_A-move-against-same-sexmarriage.html ("Geer said the same-sex marriage debate is 'about wholesale redefinition and changing of gender' and would harm children by forcing them to grow up in 'experimental families." "). Rules 1.2, 18.2.2

287. One of the most prominent campaign commercials for California's Proposition 8 warned that children would be taught to accept homosexuality in schools. VoteYesonProp8, Yes on 8 TV Ad: It's Already Happened, YouTUbe (Oct. 7, 2008), http://www.youtube.com/watch?v=0PgicgqFYP4. Rule 18.6

288. See supra notes 64 to 70 , and the accompanying text.

289. See e.g. Pedersen v. Office of Personnel Management, 881 F.Supp.2d 294 (D. Conn. 2012).

290. See, e.g., United States v. Windsor, 133 S.Ct. 2675, 2695 (2013) (holding that DOMA's definition of marriage was unconstitutional as a deprivation of the liberty of the person protected by the Fifth Amendment); Massachusetts v. U.S. Dept. of Health and Human Services, 682 F.3d 1, 16 (1st Cir. 2012) (holding that there is not adequate support by any permissible federal interest to uphold 
have found these bans unconstitutional through motions for summary judgment, ${ }^{291}$ a couple of courts have evaluated these claims through extensive hearings or full trials. Most notable among these is the federal trial on the constitutionality of California's Proposition $8 .^{292}$

One of the first extensive hearings involving a challenge to the idea of potential harm to children occurred in a state court in Florida in a case challenging the state's ban on adoption by gays and lesbians. ${ }^{293}$ The court held an extensive hearing on the constitutionality of the ban with expert witness "testimony relating to the social, psychological, interpersonal, and physical effects of same-sex relationships on individuals, families, children, and to some extent, society as a whole." 294

Much of the testimony focused on the potential harm that gay parents may have on children, with the state's expert witnesses claiming that gays and lesbians have too many psychological problems to be good parents. ${ }^{295}$ In contrast, the petitioner's expert testified that "the research shows that sexual orientation alone is not a proxy for psychiatric disorders, mental health conditions, substance abuse or smoking; members of every demographic group suffer from these conditions at rates not significantly higher than for homosexuals." 296

In an attempt to prove that children raised by gay parents are not as welladjusted as those raised by heterosexual parents, the state used Dr. George Rekers, ${ }^{297}$ a Baptist minister, as an expert who testified that gays and lesbians have higher rates of depression and mental illness, ${ }^{298}$ lack relationship stability, ${ }^{299}$

the provision of DOMA which denies federal benefits to same-sex couples lawfully married in Massachusetts); Pedersen, 881 F.Supp.2d at 347 (holding that there is no rational basis for Section 3 of DOMA and that it therefore violates equal protection).

291. See, e.g., Perry v. Schwarzenegger, 704 F. Supp. 2d 921, 927 (N.D. Cal. 2010); In re Adoption of John Doe \& James Doe, No. 2008 WL 5006172 (11th Cir. 2008) (hearing in front of Judge Lederman) aff'd., Dept. of Children and Families v. Adoption Of X.X.G., 45 So. $3 d 79$ (Fla. Dist. Ct. App. 2010).

292. See Perry v, Schwarzenegger, 704 F. Supp. 2d 921, 927 (N.D. Cal. 2010).

293. Florida's statutory ban on gay people adopting children has faced a couple different court challenges. Most famously, the ban was challenged in Lofton v. Sec'y of the Dep't. of Children \& Fam. Servs., 358 F.3d 804 (11th Cir. 2004), where the ban was held constitutional under federal law.

The ban was also challenged in state court, but the decision was never appealed. In In re Adoption of John Doe and James Doe, the court decided the constitutionality under Florida law. Doe, $2008 \mathrm{WL}$ 5006172.

294. Doe, 2008 WL 5006172, at*6.

295. Id. One expert for the state claimed that gays and lesbians suffer numerous psychological problems, including: "(1) a lifetime prevalence of significantly increased psychiatric disorders; (2) higher levels of alcohol and substance abuse; (3) higher levels of major depression; (4) higher levels of affective disorder; (5) four times higher levels of suicide attempts; and (6) substantially increased rates of relationship instability and breakup." $I d$.

296. Id. at *7.

297. Interestingly, Dr. Rekers was subsequently caught in a scandal when a local newspaper discovered that he was hiring young men as escorts. He denied any relationship with the escort, claiming that the young man only traveled with him to carry his luggage. John Schwartz, Scandal Stirs Legal Questions in Anti-Gay Cases, N.Y. TIMEs, May 19, 2010, at A15.

298. Doe, 2008 WL 5006172, at *10.

299. Id. 
and are not as good at parenting as heterosexuals are. ${ }^{300}$ Petitioner's experts countered by citing studies that showed that "the relationships of lesbians and gay men are similar in stability, quality, satisfaction, shared experiences and conflict resolution, to that of heterosexual married and unmarried couples." 301 Further, the petitioner's witnesses argued that there is a general "consensus in the field that children do not need a parent of each gender to adjust healthily." 302

After four days of testimony that often mirrored the arguments made in anti-gay initiative campaigns, the court found the testimony of the state's key witness not to be credible and held the ban on adoption by gay people to be unconstitutional under Florida law. ${ }^{303}$ In reviewing the testimony and studies presented at trial, the court found that "there are no differences in the parenting of homosexuals or the adjustment of their children." 304 The manner in which the court thoroughly analyzed the evidence before it is in direct contrast to superficial initiative campaigns, which most people evaluate without analyzing any credible evidence and instead rely on emotion, fear, personal morality, and personal experience.

As Fisher contemplated, judges have the requisite skills to analyze and

300. See Id. Interestingly, the court mentioned that this expert witness relied heavily on Cameron, see supra notes $240-248$, and the lack of credibility he has. Id. at *11, nn. 11, 23.

301. Doe, 2008 WL 5006172 at *6, nn, 4-5.

302. Id. at ${ }^{*} 10$.

303. Id. at *12 ("Dr. Rekers' testimony was far from a neutral and unbiased recitation of the relevant scientific evidence. Dr. Rekers' beliefs are motivated by his strong ideological and theological convictions that are not consistent with the science. Based on his testimony and demeanor at trial, the court can not consider his testimony to be credible nor worthy of forming the basis of public policy.").

304. Id. at *37. The court focused on a review of all of the studies done on the impact that gay parents have on children:

The quality and breadth of research available, as well as the results of the studies performed about gay parenting and children of gay parents, is robust and has provided the basis for a consensus in the field. Many well renowned, regarded and respected professionals have reduced methodologically sound longitudinal and cross-sectional studies into hundreds of reports. Some of the longitudinal studies have tracked children for six, ten and fourteen years. The starting ages of the children in the longitudinal studies has varied from birth, six to ten years old and followed them throughout childhood, adolescence and into adulthood. The studies and reports are published in many well respected peer reviewed journals including the Journal of Child Development, the Journal of Family Psychology, the Journal of Child Psychology, and the Journal of Child Psychiatry. Each of the studies and hundreds of reports also withstood the rigorous peer review process and were tested statistically, rationally and methodologically by seasoned professionals prior to publication. In addition to the volume, the body of research is broad; comparing children raised by lesbian couples to children raised by married heterosexual couples; children raised by lesbian parents from birth to children raised by heterosexual married couples from birth; children raised by single homosexuals to children raised by single heterosexuals; and children adopted by homosexual parents to those raised by homosexual biological parents, to name a few. These reports and studies find that there are no differences in the parenting of homosexuals or the adjustment of their children. These conclusions have been accepted, adopted and ratified by the American Psychological Association, the American Pediatric Association, the American Academy of Pediatrics, the Child Welfare League of America and the National Association of Social Workers. As a result, based on the robust nature of the evidence available in the field, this Court is satisfied that the issue is so far beyond dispute that it would be irrational to hold otherwise; the best interests of children are not preserved by prohibiting homosexual adoption.

Id. at $* 20$. 
assess arguments using reason, and in this case, the Florida court found these alleged harms to children to be without merit. ${ }^{305}$ Similarly, federal and state courts have evaluated alleged harms to children when deciding the constitutionality of same-sex marriage bans and found the claims meritless. California's Proposition 8 provides an excellent contrast between the ways voters and judges evaluate various arguments. Voters approved Proposition 8 after a political campaign that focused on the potential harm to children, but a federal court did not find any evidence that same-sex marriage would harm children.

\section{A. The Campaign for Proposition 8}

Opponents of marriage equality in California successfully placed on the November 2008 ballot a measure known as Proposition 8, which defined marriage in the California Constitution as a union between one man and one woman. ${ }^{306}$ The push to pass Proposition 8 took on even more importance when the California Supreme Court held that denying marriage rights to same-sex couples violated the California Constitution. ${ }^{307}$ Subsequent to this ruling, the State of California began issuing marriage licenses to same-sex couples on June $16,2008,{ }^{308}$ with more than 18,000 same-sex couples marrying before the November election. ${ }^{309}$

The supporters and opponents of Proposition 8 had very different campaign tactics and themes. ${ }^{310}$ Those supporting Proposition 8 spent most of their financing on commercials that appeared on television one month before the election. ${ }^{311}$ The Proposition 8 campaign relayed three basic messages in its advertisements: 1) parents are losing control over what their children are learning, 2) a pro-gay message is being imposed on children and society, and 3) this pro-gay message poses an immediate danger to children. ${ }^{312}$

The impact of these messages on voters is analyzed in an extensive report, The Prop 8 Report: What Defeat in California Can Teach Us about Winning Future Ballot Measures on Same-Sex Marriage. ${ }^{313}$ The report explains how proponents of Proposition 8 successfully used the idea that same-sex marriage will harm

305. FISHER, HUMAN COMMUNICATION, supra note 16 at 71 . Fisher explains how public moral arguments are often in the realm of "public-social knowledge" and that they naturally invite experts to give their voice to the dialogue. Fisher believes that this makes moral decision-making more difficult at times because untrained thinkers are unable to compete rhetorically with these experts. Id.

306. Perry v. Proposition 8 Official Proponents, 587 F.3d 947, 949 (9th Cir. 2009).

307. In re Marriage Cases, 183 P.3d 384 (Cal, 2008).

308. Rong-Gong Lin II \& Maura Dolan, The First Bells Ring at 5:01 p.m. Monday, THE L.A. TiMES, June 13, 2008, at B2.

309. Perry v. Schwarzenegger, 704 F.Supp.2d 921, 928 (N.D. Cal. 2010).

310. David Fleischer, The Prop 8 Report: What Defeat in California Can Teach Us about Winning Future Ballot Measures on Same-Sex Marriage, THE PROP 8 REPORT 11-13 (Aug. 3, 2010), https:/ / e6c677e6-a080985b6-s-sites.googlegroups.com/a/lgbtmentoring.org/prop-8-report/TheProp8Report.pdf. This extensive report contains a great deal of data about which commercials had the most impact on voters in the November 2008 election. It details each commercial, which voters the commercials influenced, and which messages seemed to change voters' minds.

311. Id. at 285 (discussing when the Proposition 8 proponents began to spend its money on the campaign).

312. Id at 89 .

313. Id. 
children, specifically focusing on how children will learn about inappropriate sexual and pro-gay material in school. ${ }^{314}$ The report also provides data to show that the main commercial promoting this message swayed approximately 5\% of the voters right before the election. The advertisement, known as the Princes ${ }^{315}$ advertisement, shows a child coming home and talking about how she learned that a prince can marry a prince and that she can marry a princess. ${ }^{316}$ This message directly played into the broader narrative that gays are harmful to children with the underlying assumption that being gay is bad. ${ }^{317}$ The advertisement also contained a message from a professor at Pepperdine University School of Law claiming that children would be taught pro-gay ideas in school at an early age if same-sex marriage remains legal, using Massachusetts as an example. ${ }^{318}$

Gay rights opponents in the Proposition 8 campaign skillfully established narrative rationality for voters by including a message about children that was supported by an expert. Specifically, the message had all of the elements of narrative fidelity - it played into the universal value of protecting our children, used fear to motivate the voter, and was supported by a legal expert. It also played into the voter's emotions and fears by focusing on how schools will take away a parent's choice to teach about sexuality (even without any clear evidence), providing material coherence to the narrative that children will be harmed-because it already happened in the first state to approve same-sex marriage, it will also happen in California.

The report provides extensive data to prove that the Princes advertisement had a dramatic effect on the election and that the narrative that same-sex marriage will harm children changed the election significantly. ${ }^{319}$ The organization supporting Proposition 8 spent more than 4.1 million dollars on this one commercial, more than any other advertisement from either side of the debate. ${ }^{320}$ This commercial aired from October 6 until November 3, 2008. ${ }^{321}$ Based on a comparison of pre-election polling and election results, the report details how approximately $5 \%$ of voters changed how they were going to vote in the last month before the election, producing a ten-point swing. ${ }^{322}$ The report ties this significant swing to the Princes commercial, showing that parents with children younger than eighteen years old accounted for the majority of voters who

314. Id. at 11 .

315. VoteYesonProp8, Yes on 8 TV Ad: It's Already Happened, YOUTUBE (Oct. 7, 2008), http://www.youtube.com/watch?v=0PgicgqFYP4. This advertisement is known as "Princes" to signify that they are talking about how two princes can marry (instead of one prince and one princess).

316. Fleischer, supra note 310 , at 49.

317. The advertisement starts with the underlying assumption that someone talking about samesex marriage to children is bad. $I d$, at 49 .

318. VoteYesonProp8, Yes on 8 TV Ad: It's Already Happened, YouTubE (Oct. 7, 2008), http:/ / www.youtube.com/watch?v=0PgjcgqFYP4.

319. Fleisher, supra note 310, at 49-61 (analyzing the message of the advertisement and the shift of public support at the time the commercial aired).

320. Id. at 23 .

321. Id.

322. Id. at $25-48$. 
switched their votes in the last month before the election, when the Princes commercial ran on television. ${ }^{323}$ The timing of the swing in voter attitudes suggests that the commercial "rang true" to these parents and played into their deeply-seated value of protecting their children and maintaining their right to teach their children about morality.

Meanwhile, the opponents of Proposition 8 did not attempt to rebut the Princes commercial until a few weeks later, immediately before the election. ${ }^{324}$ Instead, gay rights proponents based most of their advertisements on several themes: 1) that the state should treat everyone equally, 2) that the proposition is bad and unfair for many reasons, 3) that the proposition will take away rights granted to a group of people and 4) that the proposition is blatant discrimination. ${ }^{325}$ Voters likely had a difficult time connecting to these reasons because they failed to capitalize on any common experiences and universal values, such as family, which the opponents of same-sex marriage did well. ${ }^{326}$ Gay rights proponents missed an opportunity to connect the experiences of voters to those of same-sex parents, while gay rights opponents effectively established narrative rationality by focusing their commercials on the impact same-sex marriage will have on the voter's family. ${ }^{327}$ As Fisher's narrative paradigm details, people are more likely to accept a proposition that aligns with their own lives and experiences than one that does not immediately connect with the recipient of the message. ${ }^{328}$

The success of the Princes commercial also illustrates the dangers of initiative campaigns. Political advertisements can easily tap into well-developed narratives even when the arguments are not based in fact, as long as they connect to the voters' values and experiences. ${ }^{329}$ An initiative campaign can successfully move voters with a clear message that capitalizes on an already developed narrative, has strong narrative rationality, and is not immediately rebutted. The clear and unchallenged message by gay rights opponents in the Proposition 8 campaign likely led a large number of voters to switch sides during the month before the election, showing the continued success of the narrative that gay people harm children and the ineffectiveness of gay rights proponents' broad concepts of fairness and equality. ${ }^{330}$

323. Id. at 25-26 ("Most of the movement away from same-sex marriage happened within groups that were at the start part of No on 8 's base ... [with] consistent gains among parents and voters of parenting age who were Democrats and Independents."). The report details that approximately 500,000 parent voters with children under eighteen moved away from supporting same-sex marriage in the final six weeks of the campaign. $I d$. at 32 .

324. Id. at 76 .

325. Id. at $88-89$.

326. Id. at 49-61.

327. Many complaints about the No on 8 campaign focused on how it avoided discussing gay people and their families. Id. at 73 ("No on $8 \ldots$ avoided depiction of LGBT people, the centrality of LGBT people in the issue at hand, and even use of the word 'gay' or any other word that would communicate the fundamental truth that LGBT people are the ones most directly affected by the ballot measure."). Rule 1.5

328. Fisher, Paradigm, supra note 81.

329. Id. at 47 .

330. Fleischer, supra note 310 , at 49-61. 


\section{B. The Federal Trial on the Constitutionality of Proposition 8}

While the campaign for Proposition 8 showed how the use of short television commercials can successfully use well-developed narratives to win elections, the judicial process does not generally allow for such superficial persuasion. As Fisher's narrative paradigm envisions, rational argument is best used in a forum where the participants have the expertise and ability to use reason to evaluate an argument, such as in a court. ${ }^{331}$ After Proposition 8 passed, a lawsuit was filed in federal court challenging the constitutionality of the new amendment with the hope that the court would thoroughly vet the arguments made by Proposition 8 's supporters. ${ }^{332}$ To fully assess the arguments made by both sides of the Proposition 8 debate, the Northern District of California held a full trial on the constitutionality of the proposition. ${ }^{333}$

Much of the testimony and arguments made by the proponents of Proposition 8 focused on the danger that same-sex marriage would pose to children. ${ }^{334}$ The court summarized the arguments presented during the campaign:

Children will be forced "to recognize or acknowledge the existence of same-sex couples."

Denying marriage to "same-sex couples protects children."

The ideal environment to raise a child is with one mother and one father. ${ }^{335}$

At court, those defending Proposition 8 continued to advance the argument that it is best for children if they have one mother and one father. ${ }^{336}$ In advancing the argument that same-sex marriage will harm children, they introduced an expert witness, David Blankenhorn, who testified that the optimal environment in which to raise a child is with biological parents, a common argument made during the initiative campaign ${ }^{337} \mathrm{He}$ pointed to studies that compared children raised by married, biological parents with children raised by single parents, unmarried mothers, step-families, and cohabitating couples. ${ }^{338}$ The studies he used did not compare married, biological families to same-sex spouses with children. ${ }^{339}$ To counter this testimony, the opponents of Proposition 8 presented their own expert witness who testified that "all available evidence shows that children raised by gay or lesbian parents are just as likely to be well-adjusted as children raised by heterosexual parents and that the gender of a parent is

\footnotetext{
331. FISHER, HUMAN COMMUNICATION, supra note 16, at 71.

332. Perry v. Schwarzenegger, 704 F. Supp, 2d 921 (N.D. Cal, 2010).

333. Id.

334. Id. 947-952.

335. Id. at 930. The court also listed the following as other premises for Proposition 8: 1) The denial of marriage preserves marriage, 2) Opposite-sex couples are different from and superior to same-sex couples, and 3) Same-sex marriage redefines the idea of marriage. $I d$.

336. Id.

337. Id. at 931 .

338. Id. at 935 .

339. Id. at 948 .
} 
immaterial to whether an adult is a good parent." 340 Another expert witness for the opponents of Proposition 8 testified that same-sex and opposite-sex couples do not differ in terms of the quality and stability of the relationship. ${ }^{341}$ After the testimony, the court examined all of the arguments and testimony and concluded that the expert testimony supporting Proposition 8 was unreliable. ${ }^{342}$ The judge's process of using logic and reason to analyze the arguments made by both sides was in stark contrast to how swing voters likely analyzed the proposition by watching several thirty-second commercials during the campaign.

In finding that Proposition 8 was unconstitutional, the court issued an opinion with more "Findings of Fact" than "Conclusions of Law," highlighting the emphasis it placed on analyzing the factual arguments made by both sides. 343 Even when presented with all of the evidence that same-sex marriage could harm children, the court found that same-sex marriage does not negatively affect children:

The benefits of marriage flow to their children regardless of the gender of the parents. ${ }^{344}$

Same-sex couples are equally satisfied as opposite-sex couples, and they are equally able to have stable relationships. 345

"The children of same-sex couples benefit when their parents can marry."346

The sex of the parents is not material to the development of a child. ${ }^{347}$

Through the extensive testimony at trial, the court was able to fully assess the arguments made about any potential harm that would result from same-sex marriages. After all of this testimony, and in direct contrast to the initiative process, the court was able to break the long-argued narrative that gay people are harmful to children. ${ }^{348}$ With this narrative thoroughly debunked, the court held that Proposition 8 had no legitimate purpose and was unconstitutional. ${ }^{349}$

The potential harm caused by same-sex marriage was also argued in numerous briefs filed in the two marriage cases that appeared before the United States Supreme Court in March 2013.350 It also was discussed during the oral

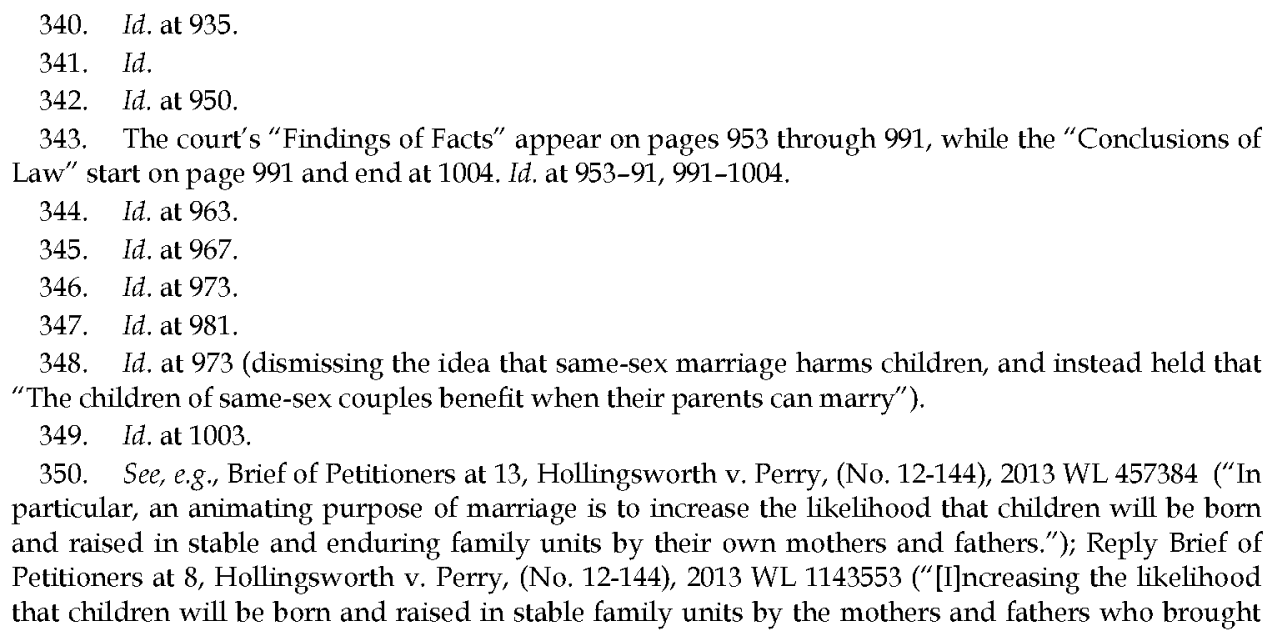
particular, an animating purpose of marriage is to increase the likelihood that children will be born and raised in stable and enduring family units by their own mothers and fathers."); Reply Brief of Petitioners at 8, Hollingsworth v. Perry, (No. 12-144), 2013 WL 1143553 ("[I]ncreasing the likelihood that children will be born and raised in stable family units by the mothers and fathers who brought 
arguments. ${ }^{351}$ After the arguments, the court did not find that same-sex marriage caused any harm to children..$^{352}$ Instead, the court pointed to the harm that bans on same-sex marriage have on children with gay parents:

And it humiliates tens of thousands of children now being raised by same-sex couples. The law in question makes it even more difficult for the children to understand the integrity and closeness of their own family and its concord with other families in their community and in their daily lives. 353

Each of these cases illustrates how courts are better equipped than voters to analyze potential harm to children. No matter how much expert testimony and research was presented to the courts, they still found absolutely no harm to children. ${ }^{354}$ Instead, the courts began to focus on how the denial of marriage equality negatively impacts the children of same-sex parents. 355 This process has helped break the decades-long negative narratives about gay people and samesex marriage.

\section{CONCLUSION: DeVEloping NeW AND POSITIVE NARRATIVES ABOUT GAYS AND LESBIANS AND THEIR FAMILIES}

Proponents of marriage equality have seen their efforts come to fruition over the past year, with the U.S. Supreme Court holding DOMA unconstitutional and a few states implementing marriage rights through the political process. 356 These developments can be attributed to the narrative about gay people moving

them into the world"); Amicus Curiae Brief for Catholics for the Common Good and the Marriage Law Project in Support of Petitioners at 29, Hollingsworth v. Perry, (No. 12-144), 2013 WL 416203 ("Children thrive in a stable, low-conflict, committed relationship created and sustained by both [biological parents]."); Brief on the Merits for Respondent the Bipartisan Legal Advisory Group of the U.S. House of Representatives at 48, United States v. Windsor, (No. 12-307), 2013 WL 267026 ("Moreover, the different challenges faced by boys and girls as they grow to adulthood make it at least rational to think that children benefit from having parental role models of both sexes."); Brief Addressing the Merits of the State of Indiana and 16 Other States as Amici Curiae in Support of Respondent the Bipartisan Legal Advisory Group of the U.S. House of Representatives at 17, United States. v. Windsor, (No. 12-307), 2013 WL 390993 ("It is the institution that provides the greatest likelihood that both biological parents will nurture and raise the children they beget, which is optimal for children and society at large."); Amicus Curiae Brief of Coalition for the Protection of Marriage in Support of Hollingsworth and Bipartisan Legal Advisory Group Addressing the Merits and Supporting Reversal at 21, United States v. Windsor, (No. 12-307), 2013 WL 1780812 ("One of the social goods produced uniquely by the man-woman meaning at the core of the marriage institution is protection of the child's interest in knowing and being brought up by his or her biological parents, with exceptions being justified only in the best interests of the child, not for the gratification of any adult desires.").

351. See, e.g., Transcript of Oral Argument at 59, Hollingsworth v. Perry, 133 S. Ct. 2652 (2013)(No. 12-144) ("It denies to the - to the parents who want to marry the ability to marry, and it denies to the children, ironically, the very thing that Petitioners focus on is at the heart of the marriage relationship.").

352. Perry v. Schwarzenegger, 704 F. Supp. $2 d$ at 973.

353. United States v. Windsor, 133 S. Ct. 2675, 2694 (2013).

354. See Windsor, 133 S. Ct. at 2694; Perry, 704 F. Supp. 2 d at 973.

355. See e.g., Perry, 704 F. Supp. 2d at 973; Windsor, 133 S. Ct. at 2694.

356. Windsor, 133 S. Ct. at 2694; David Sharpe, A Festive Mood in Maine as Same-Sex Marriage Becomes Legal, NY TIMES, Dec. 26, 2012, at A20, available at http://www.nytimes.com/2012/ $12 / 30 /$ us / same-sex-marriage-becomes-legal-in-maine.html?src =recg\&_r $=0$. 
away from one that focused on how gay people and same-sex marriage are likely to harm children. ${ }^{357}$ By using the courts to break the narrative that gay people harm children, gay rights activists have been able to develop a completely new and positive narrative - that they are fit parents, and bans on marriage equality hurt their children. ${ }^{358}$

The manner in which gay rights activists used the court system to advance marriage equality is an example of the possible role that courts can play in helping advance social change. After courts allowed same-sex couples to marry in a few states, more people were exposed to same-sex couples. ${ }^{359}$ This exposure provided people with personal experiences that ran counter to the narratives pushed by opponents of same-sex marriage. ${ }^{360}$ Because popular culture tends to reflect society, television shows, books, and movies began exposing more people to same-sex couples, for example the television shows the New Normal and Modern Family, ${ }^{361}$ a children's book about same-sex penguins, ${ }^{362}$ and movies such as the upcoming animated film The Boxtrolls. ${ }^{363}$ More parents were meeting gay parents at schools, and children were making friends with children with gay parents. ${ }^{364}$ All of these experiences helped challenge the narrative rationality of the argument that gay people harm children and produced a more positive narrative in its place. In fact, even President Obama discussed how his views about same-sex marriage began to change when hearing stories from his daughters and meeting more same-sex couples. ${ }^{365}$

357. See e.g., Windsor, 133 S. Ct. at 2694.

358. See e.g. id.; Perry, 704 F. Supp. 2 d at 973.

359. For an estimate of the growing number of married same-sex couples, see Drew DeSilver, How Many Same-Sex Marriages In The U.S.? At Least 71,165, Probably More, PEW RES. CTR., (June 26, 2013), http://www.pewresearch.org/fact-tank/2013/06/26/how-many-same-sex-marriages-in-theu-s-at-least-71165-probably-more/. See Janice D'Arcy, For Same-Sex Parents, How 'Out' To Be At School?, WASH. POST, (Aug. 20, 2012, 12:05 PM), http://www,washingtonpost.com/blogs/onparenting/post/ for-same-sex-parents-how-out-to-be-at-school/2012/08/30/500637ca-f23b-11e1-

adc6-87dfa8eff430_blog.html (discussing the increasing acceptance of same-sex parents in schools).

360. DeSilver, supra note 359; D'Arcy, supra note 359.

361. See Bruce Feiler, What 'Modern Family' Says About Modern Families, L.A. TIMES, January 23, 2011, at ST1, available at http://www.nytimes.com/2011/01/23/fashion/23THISLIFE.html?_r=1\& (discussing how Modern Family captures contemporary families well); Maria Puente, Hollywood Now Opening Arms to Gay Characters, Families, USA TODAY, August 24, 2010, at B8, azailable at http://usatoday30.usatoday.com/life/movies/news/2010-08-24-gayshollywood23_CV_N.htm;

Brian Stelter, Gay on TV: It's All in the Family, N.Y. TIMES, May 8, 2012, at A1, available at http://www.nytimes.com/2012/05/09/business/media/gay-on-tv-its-all-in-the-family.html.

362. Peter PARnell \& Justin Richardson, AND TANGO MAKES THREe (2005) (a story about two same-sex penguins who care for an egg).

363. Christopher Rudolph, 'The Boxtrolls' Trailer, New Animated Film By Laika, Features Gay Parents, THE HUFFINGTON POST (July 3, 2013, 11:38 AM), http://www.huffingtonpost.com/2013/ 07/03/the-boxtrolls-trailer-laika-gay-parents_n_3540489.html. Rule 18.2.2

364. See D'Arcy, supra note 359.

365. See Peter Wallsten \& Scott Wilson, Obama Endorses Gay Marriage, Says Same-Sex Couples Should Have Right to Wed, WASH. POST, May 9, 2012, at A1, available at http://articles.washingtonpost.com/2012-05-09/politics/35456733_1_gay-marriage-gay-rightsactivists-president-obama (quoting President Obama:

You know, Malia and Sasha, they have friends whose parents are same-sex couples. There have been times where Michelle and I have been sitting around the dinner table and we're talking about their friends and their parents and Malia and Sasha, it wouldn't dawn on 
This new cultural shift on same-sex marriage helped change the political landscape as well. Instead of just passing bans on same-sex marriage, legislatures and voters began to approve marriage rights for same-sex couples without being forced by a court to act. ${ }^{366}$ A perfect example is what happened in Maine, where the legislature and governor approved same-sex marriage in 2009, but the law was subsequently reversed by popular vote. ${ }^{367}$ Just three years later, Maine voters changed their views and approved same-sex marriage in November 2012. ${ }^{368}$ Maryland and Washington also approved same-sex marriage by popular vote in November 2012.369 In these ballot campaigns, proponents of same-sex marriage began to use the new narrative that children of same-sex couples are harmed by marriage bans, and their success shows that this new narrative began to have rationality to voters. ${ }^{370}$

The changing narrative about same-sex parents and spouses even became part of the arguments to and opinions from the Supreme Court, where Justice Kennedy saw how marriage equality could help children raised by same-sex parents. During oral arguments in Perry v. Brown, Justice Kennedy asked how bans on same-sex marriage harm the children of same-sex parents:

On the other hand, there is an immediate legal injury or legal-what could be a legal injury, and that's the voice of these children. There are some 40,000 children in California, according to the Red Brief, that live with same-sex parents, and they want their parents to have full recognition and full status. The voice of those children is important in this case, don't you think?371

It was also central to his opinion in United States $v$. Windsor, 372 which has already had the effect of legitimizing same-sex marriage and gay parenting in constitutional law. Without going to court or exposing more people to same-sex spouses with children, gay rights activists would have had a much more difficult time changing the narrative that same-sex marriages will somehow harm children, as seen in the dozens of successful initiatives limiting marriage equality. The result may have ultimately been the same, but it would have taken much longer for our culture and voters to accept a new narrative about gay

them that somehow their friends' parents would be treated differently. It doesn't make sense to them and, frankly, that's the kind of thing that prompts a change in perspective.).

366. Sharpe, supra note 356.

367. North Cairn, For Same-Sex Couples, Marriage is Vindication, PORTLAND PRESS HeRALD, November 11, 2012.

368. Id.

369. It.

370. Aaron C. Davis, In Maryland, 'For the Kids' is an Evolution in the Campaign for Same-Sex Marriage, WASH. POST, October 13, 2012, available at http://articles.washingtonpost.com/2012-1013/local/35499961_1_marriage-law-twin-boys-kids-of-gay-parents ("a campaign message pushed Gov. Martin O'Malley... [who] often says, 'for the kids'."); Nathaniel Frank, How Gay Marriage Finally Won at the Polls, SLATE, (Nov, 7, 2012, 2;00 AM) http://www.slate.com/articles/ news_and_politics/politics/2012/11/gay_marriage_in_maryland_and_maine_the_inside_strategy.si ngle.html (discussing how the focus on love, commitment, and family showed that same-sex couples have a commonality with heterosexual couples).

371. Transcript of Oral Argument at 21, Hollingsworth v. Perry, 133 S. Ct. 2652 (2013) (No. $12-$ 144).

372. United States v. Windsor, 133 S. Ct. 2675, 2695 (2013) ("DOMA also brings financial harm to children of same-sex couples."). 
people if the courts had not intervened and given it rationality.

Although no social cause or minority group is the same, the fight for marriage equality can provide some lessons for other groups who seek equality under the law. These lessons are especially relevant to those groups, such as immigrants and transgender individuals, whose identities are not readily apparent to the general public and who often lack visibility and are unable to immediately rebut negative narratives. Some well-developed narratives are already being used to limit the rights of people in these groups by using terms like "illegal immigrants" 373 and focusing on bathroom issues when discussing transgender individuals. ${ }^{374}$ Immigrants and transgender people, for example, will need to "come out of their closets" and begin defining their own narratives that advance their rights. They may even need to do this outside of the ordinary political system.

We are beginning to see some movement in immigration law for children who are in the United States illegally because of their parents, largely due to the changing narrative and the visibility of these children in society. ${ }^{375}$ Within the past few years, these children have begun developing a narrative that focuses on how they are in the military or attending college, which is much different than the label "illegal immigrants" would suggest. ${ }^{376}$ Even the proposed bill to give these children rights is called the "DREAM Act" 377 which is much more positive and taps into our value of "living the American dream." These events have helped undermine the narrative rationality of the idea that they are criminals. ${ }^{378}$ Transgender activists have also attempted to change negative narratives about them by telling stories about young children who do not conform to society's gender stereotypes, providing rationality to the narrative that transgender people do not choose to struggle with the gender. ${ }^{379}$

373. See Deirdre Edgar, L.A. Times Updates Guidelines for Covering Immigration, LA TIMES, (May 1, 2013, 4:11 PM), http://www.latimes.com/news/local/readers-rep/la-me-rr-la-times-guidelinesimmigration-20130501,0,5876110.story.

374. See Dean Spade, Documenting Gender, 59 HASTINGS L.J. 731, 776-77 (2008) ("Anxieties about transgender people, especially stereotypes about transgender people as imposters or as sexual predators, frequently emerge in controversies over sex-segregated facilities like bathrooms.").

375. See, e.g., Janell Ross, Dream Act Activists Push Into Mainstream With American Protest Movement Tactics, THE HUfFINGTON POST (Aug. 21, 2012, 8:46 AM), http://www.huffingtonpost.com/2012/08/21/dream-act-activists-protest-tactics_n_1813273.htm1.

376. Id.

377. For a thorough overview of the proposed immigration legislation called the DREAM Act, go to the National Immigration Law Center at http://nilc.org/dreamsummary.html

378. David Nakamura, Push To Legalize Children Of Illegal Immigrants Is New Flash Point In Debate, WASH. POST, (August 12, 2013), http://articles.washingtonpost.com/2013-0812/politics/41318277_1_illegal-immigrants-house-republicans-dream-act (discussing the arguments for the DREAM Act, including the argument that "These children came here through no fault of their own and many of them know no other home than the United States").

379. See, e.g., Ed Payne, Transgender First-Grader Wins the Right to Use Girls' Restroom, CNN (June 24, 2013, 3:15 PM), http://www.cnn.com/2013/06/24/us/colorado-transgender-girl-school. 
As was the case with gay rights, some of these negative narratives may be impossible to break culturally or through the political process because they are so well established, which may require that they use the judicial system instead. ${ }^{380}$

380. Many minority groups will never have the political strength and ability to break narratives that have been developed by their political opponents. Nevertheless, technology and social media may provide these groups access to more people in an effort to develop new narratives. Such access was not available to gay rights activist until the past decade. See Alex Kantrowitz, Jose Antonio Vargas on Using Social Media to Change Perceptions and Policy, PBS (May 20, 2013), http://www.pbs.org/mediashift/2013/05/jose-antonio-vargas-on-using-social-media-to-changenarratives-culture-and-policy. 